Max-Planck-Institut für demografische Forschung

Max Planck Institute for Demographic Research

Konrad-Zuse-Strasse 1 - D-18057 Rostock · GERMANY

Tel +49 (0) 3812081 - 0; Fax +49 (0) 3812081 - 202;

http://www.demogr.mpg.de

MPIDR WORKING PAPER WP 2005-014

JUNE 2005

\title{
Childlessness and educational attainment among Swedish women born in 1955-59
}

Jan M. Hoem (hoem@demogr.mpg.de)

Gerda Neyer (neyer@demogr.mpg.de)

Gunnar Andersson (andersson@ demogr.mpg.de)

(C) Copyright is held by the authors.

Working papers of the Max Planck Institute for Demographic Research receive only limited review. Views or opinions expressed in working papers are attributable to the authors and do not necessarily reflect those of the Institute. 
JMH, GRN, KGA, 13 June 2005

\title{
Childlessness and educational attainment among Swedish women born in 1955-59
}

by Jan M. Hoem, Gerda Neyer, and Gunnar Andersson

\begin{abstract}
In this paper, we extend the concept of educational attainment to cover the field of education attained in addition to the conventional level of education. Our empirical investigation uses register records containing childbearing and educational histories of an entire cohort of women born in Sweden (about a quarter-million individuals). This allows us to operate with a high number of educational field-and-level combinations (some sixty in all). It turns out that the field of education serves as an indicator of a woman's potential reproductive behavior better than the mere level. We discover that in each field permanent childlessness increases (some) with the educational level attained, but that the field itself is the more important. In general, we find that women educated for jobs in teaching and health care are in a class of their own, with much lower permanent childlessness than in any other major grouping at each educational level. Women educated in arts and humanities or for religious occupations have unusually high fractions permanently childless.

Our results cast doubt on the assumption that higher education per se must result in higher childlessness. In our opinion, several factors intrinsic and extrinsic to an educational system (such as its flexibility, its gender structure, and the manner in which education is hooked up to the labor market) may influence the relationship between education and childlessness, and we would not expect a simple, unidirectional relationship.
\end{abstract}


Abstract 1

1. Introduction 3

2. Why fertility research should pay attention to institutional aspects and to the woman's field of education 5

2.1. Childbearing and the educational system 5

2.1.1. Flexibility 6

2.1.2. Gender structure 6

2.2. Education and the labor market 8

2.2.1. Job security 8

2.2.2. Job content 9

2.2.3. Skill depreciation 9

2.2.4. Gender dominance 10

3. The Swedish educational system 11

4. Main results 15

4.1. Main features $\quad 15$

4.2. Childlessness and mean age at completion of education 17

4.3. Outliers 18

5. Reflections on our main findings $\quad 20$

5.1. The gender structure of the educational system 20

5.2. Education and the labor market 22

5.3. Selection and adaptation $\quad 24$

6. Education and fertility - some implications for future research 25

Acknowledgements 26

References $\quad 27$

$\begin{array}{ll}\text { Figures } & 38\end{array}$

Appendix 1. Data 41

A1.1. The register data 41

A1.2. Coding of educational attainment 43

A1.3. Data cleaning $\quad 44$

A1.4. Method of analysis $\quad 46$

Appendix 2: Table A2 49 


\section{Introduction}

This paper is about the association between educational attainment and permanent childlessness among women. There is a lot of interest in this issue in the academic literature and lately also in the public debate. One of the most common perceptions about the effect of educational attainment on childbearing is that more education leads to lower fertility. Manifold explanations have been given for such an observation. Economists argue that higher education results in higher opportunity costs of childbearing for mothers (because they get lower rewards for their investment into education) and in higher direct costs of children (because more highly educated parents invest more than others in each child); this should lead to lower fertility (Becker 1960, 1981; Cigno 1991). It is further argued that higher education reduces a woman's economic dependence on a (male) earner (Oppenheimer 1994). This would increase the share of non-married women among the highly educated at each stage in life, which in turn would lead to a higher observed rate of childlessness among highly educated women when marital status is disregarded in the empirical analysis (Grünheid 2004; Blossfeld and Jaenichen 1992a; Blossfeld and Huinink 1991; Kiernan 1989; Hobcraft and Kiernan 1995).

Scientists focusing on cultural issues often interpret fertility differentials among women at different educational levels as a consequence of the greater range of possible lifestyles and other choices increasingly available to women as their educational attainment improves (Lesthaeghe 1983; van de Kaa 1987; 1996; Surkyn and Lesthaeghe 2004; Lappegård 2002). The wish for children is assumed to lose out in this greater range of options. In a similar vein it is argued that women lower their preferences for children as they proceed with their education (Rindfuss, Morgan, and Offutt 1996). Finally, a higher rate of childlessness among more highly educated women is in part attributed to their longer stay in education. Empirical studies regularly find that childbearing rates are lower during periods of enrolment in education, irrespective of which level of education a woman has attained already. Prolonged education may therefore lead to a postponement of childbearing up to an age when biological factors may make it more difficult to conceive (Rindfuss and Bumpass 1976; Rindfuss, Bumpass, and St. John 1980; Kravdal 2001; Gustafsson 2001). 
On the whole, most researchers who study the association between educational attainment and fertility focus on two dimensions of education: First, they concentrate solely on the level of education and its impact on fertility. Second, they perceive educational attainment primarily as an individual attribute and use it as a proxy for a person's human, economic, cultural, and to some extent biological capital. We add two new dimensions to this picture, namely the field of education and institutional aspects of the educational system. We show that the field of education is an essential determinant of ultimate childlessness, and point out that institutional aspects of the educational (and occupational) system play a central role in shaping final fertility outcome. One may get a distorted impression of the relationship between education and fertility if either of these two extra dimensions is left out of account.

We spell out our reasons in Section 2. To understand better the mechanism of childbearing decisions, we pay attention to (i) the structure and flexibility of an educational system, and (ii) the relation between the educational system and the labor market. With our application to Sweden in mind we devote Section 3 to a description of the main features of the Swedish educational system.

Section 4 contains the main results of our investigation, namely the empirical relationship between the field of education and permanent childlessness in Sweden. Like most others, we find lower fertility (in the present paper manifested as higher permanent childlessness) to be associated with more education for women in each educational field. It turns out, however, that the field of education is at least as important as the level attained, so that we cannot generally maintain the assumption that higher education leads to lower fertility.

In a companion paper (Hoem, Neyer, Andersson 2005) we will extend this exploration by a study of the connection between a woman's field of education and her ultimate number of children. We split the material in this manner because it is too extensive for a single paper.

Both papers use the same data set, namely register records containing individual-level childbearing and educational histories of women born in Sweden since 1945. We have concentrated our presentation in both papers on the cohort of women born in 1955-59. We have chosen this single five-year birth cohort in part because we have wanted to focus on women who largely had reached the end of their reproductive 
period at the time of data extraction, but also for reasons of data quality. Younger cohorts have not become old enough and older cohorts have worse data (see Appendix 1). ${ }^{1}$ Extensive cleaning and reorganization of the original register data has been needed, but the details of that process are not essential for an understanding of our findings, so we have relegated an account to Appendix 1 along with some reflections on our (very simple) method of analysis.

It is legitimate to ask whether the character of our results can be replicated in other settings. In a parallel investigation based on Norwegian register data for the cohort born in 1954-58, Lappegård $(2001,2002)$ has shown that this is the case for Norway. It remains to be seen to what degree these findings can be extended to other types of countries.

\section{Why fertility research should pay attention to institutional aspects and to the woman's field of education}

To focus on the level of education alone means that one only pays attention to a single dimension of an educational system, namely its vertical differentiation. It is important to also take into account its horizontal differentiation, viz., the field, line or type $^{2}$ of education, because the choice on this dimension is also part of what determines a person's environment during her formative years and subsequently her further life course. Both impact on her childbearing behavior. The choice of education also has a decisive impact on a person's future employment, so we need to consider the ways in which education and the labor market are connected. Let us now address each of these issues in turn.

2.1. Childbearing and the educational system. The structure of the educational system is of course decisive for a person's educational career, for the level of education that a person attains, as well as for the field in which she takes her education. Several aspects of the structure potentially have an impact on fertility, but to our knowledge they have so far not been considered in demographic research. One may speculate whether, for example, educational systems with an integrated scheme of vo-

\footnotetext{
${ }^{1}$ We get largely the same results when we check the less complete data for the neighboring five-year cohorts, but we do not report any details about them here.

${ }^{2}$ We use the terms "field", "type", and "line" of education as synonymous with each other and with "educational orientation" in our papers.
} 
cational training have different consequences for childbearing behavior than educational systems where vocational training is provided through apprenticeships in firms - given, for example, that these two systems involve different environments during instruction and different timings of entry into the labor market. Similarly, one may generate hypotheses about childbearing consequences of educational systems that require early decisions about the educational career vs. educational systems that do not separate pupils at an equally early stage in life. We believe that two endogenous features are particularly relevant, namely (1) the system's flexibility and (2) the gendered pattern of educational fields. Here is why we think that these two aspects are important for fertility research.

2.1.1. The flexibility of the educational system. Educational systems vary in their flexibility. Some educational systems (e.g.: those of the Nordic countries) are highly permeable, allowing pupils and students to change their educational tracks, to alter their main field of education (within wide bounds) at all levels, and even more importantly to exit from post-compulsory education and to re-enter it at all stages in their lives. Other educational systems are more rigid and have limited opportunities for pupils and students to modify their educational decisions, to alter their field of education, or to resume education after interruption. Such differences in system flexibility must have an impact on fertility. Flexible educational systems offer a person better opportunities to adjust her education to the development of her interests and talents, to changes in the life-course (Henz 2001), and to changes in her plans for her future life. A flexible educational system should therefore make it easier for a woman to have children because she does not need to see childbearing as having an irrevocable impact on all other aspects of her life course.

2.1.2. The gendered structure of the educational system. Most educational systems are sex-segregated. Over recent decades, the gender differences in the level of educational attainment have diminished as the share of women participating in education beyond the primary level has increased in most countries. In much of the West, women now constitute the majority among entrants, participants, and graduates at the secondary level and in some fields even at the tertiary level (Jönsson 1999; OECD 1998, 92; OECD 2001, 41; Müller and Wolbers 2003).

The restructuring of gender patterns in fields of education has not matched the development in the levels of education, however. In fact, the gender division in the 
types of education has remained remarkably persistent (Bradley 2000). Even in Sweden, which has made special efforts to reduce such gender gaps, women and men have largely continued to choose different fields of education. Girls and women usually crowd into educations for care, nursing, and other health occupations, and into teaching, arts, humanities, and personal services, while as before boys and men crowd into educations for crafts, trade, industry, engineering, and the natural sciences (OECD 2001, 173; Melkas and Anker 1998; Smyth 2003, 61f.; Charles and Bradley 2002). In these fields, the gendered pattern of female- vs. male-dominated lines occurs on all educational levels; in other fields, for example business and administration, the gender distribution changes as one progresses from one level to the next. ${ }^{3}$

The growing tendency among women to take higher education has altered their childbearing behavior. Most notably, the greater participation in education has contributed much to the increase in the age at first birth seen in most countries. We know less about the effect on childbearing behavior of the narrowing gender gap at each educational level on the one hand and the persistence of gender segregation across educational fields on the other. An increase in the share of women in education alters girls' and women's social environment during the time they are in education. They stop being “token" women or a "skewed” group (Kanter 1977a; 1977b) and no longer constitute a minority so small that their socialization in school is primarily determined by the norms, attitudes, and behavior of men (Kanter 1977b). They have greater opportunities of socializing with other girls and women at the same educational level in the same educational field, including communicating about reproduction (Watkins 1995). They have better options of "doing gender" and they thus have a broader spectrum available for developing their own identity, including their identity as women and potential mothers (West and Zimmerman 1987; West and Fenstermaker 1995; Gildemeister/Wetterer 1992; Dausien 1999). Contrary to a purely economic point of view, which ties fertility to opportunity costs only, one would therefore expect that childlessness among highly educated women would decrease as the share of women with higher educational attainment or in specific educational fields increases.

\footnotetext{
${ }^{3}$ According to a recent study, education at the upper-secondary level in the social sciences and in business is female-dominated (more than $60 \%$ female) in all European countries, while at the tertiary level the female dominance vanishes (between $40 \%$ and $60 \%$ female; Smyth 2003, 63).
} 
By a similar argument, studying in female-dominated lines may provide an educational environment that encourages subsequent childbearing. Some femaledominated lines (such as home economics) are even often regarded as conveying more stereotyped images than others of womanhood and motherhood. The lines that have such a stereotyping function may vary from country to country and may change over time, but they are assumed to reinforce women's self-perception as mothers and carers. Even when they do not transmit stereotyped images of womanhood, femaledominated educational lines are nowadays often seen as providing a more supportive environment for women than male-dominated fields of education. (For a review of the literature see Jacobs, 1996. $)^{4}$ Being educated in a female-dominated field may therefore support a life-course orientation that comprises both a professional career and having children. This should work toward lower childlessness among women who have got their education in a female-dominated area than among other women at the same educational level.

Summarizing our discussion we conclude that several factors intrinsic to educational systems cast doubt on the assumption that higher education per se must result in higher childlessness. If we recognize the institutional aspects of educational systems, such as their organization (e.g. flexibility) and their structure (e.g.: their gender structure), we need to include indicators that pick up their impact on fertility. Both the level and the field of education can serve this function.

2.2. Education and the labor market. We now turn to aspects that may affect the relationship between educational attainment and childbearing behavior through the link between education and the labor market. The main lines of that link are that a woman's field of education will have a decisive impact on her future labor-market options, on how easy it becomes to "use" her education in the labor market, on her work-place environment, on the stability and protection of her employment, and on her income perspectives (See contributions in Müller and Gangl 2003). All of these features have important bearings on her childbearing behavior. For the sake of a systematic approach, we briefly outline four aspects that are relevant for our topic.

2.2.1. Job security. Different types of education lead to occupations with different employment security. In particular, some educations lead to jobs in the public

\footnotetext{
${ }^{4}$ Jacobs reports on studies that compare women-only colleges to co-educational ones, but the findings should also apply to female-dominated fields of education in general.
} 
sector more readily than others. Examples are educations for teaching, nursing, welfare, and police work, and in some countries also education in law or the medical or pharmaceutical professions. In Scandinavia, and also in many other countries, the public sector offers much better job security than the private sector does. In many countries, the public sector has also pioneered work arrangements that facilitate the compatibility of motherhood and employment, such as granting parental leave and part-time work with a guarantee of job continuation and return to full-time work after the end of the early childrearing period, or such as offering additional income compensations to a parent on parental leave. We therefore expect women with an education that leads to employment in the public sector to display lower childlessness than women with an education that leads to predominantly private-sector employment. In other words, women with an education as nurses should have lower childlessness than women with educations for textile work, the hotel- and restaurant business, or business and private administration; likewise women trained to be high-school teachers are expected to have lower childlessness than women educated in journalism.

2.2.2. Job content and job prospects. Fields of education vary concerning the prospect of finding a job one is trained for. Some educational lines may have a considerable mismatch with available occupations, and for some there may in fact be no obvious set of occupations that the education leads to. Typical examples are general educational degrees or certificates, for instance in fine arts, humanities, or general language skills. Persons with such a background must often go through a prolonged job search and may end up with a lower occupational status than they expected, fewer occupational rewards, lower income, or a higher risk of unemployment (Allmendinger 1989; Wolbers 2003; Konietzka 2002; Gangl 2003a; 2003b). In such a situation motherhood may be postponed and permanent childlessness may be more likely.

\subsubsection{Skill depreciation. The problem of skill depreciation during periods of} absence from the job is much more acute for some educations than for others. In general, technological skills tend to depreciate more quickly than skills in the service sector. ${ }^{5}$ Because they risk that their skills become outdated if they take a job break,

\footnotetext{
${ }^{5}$ In such matters, the structure of the educational system may be important, as is whether it provides firm-specific education or more general, occupation-specific education (Estevez-Abe et al., 2001). There is also some variation over time. For example, technological advancement in an area like information technology has made specific qualifications such as secretarial skills
} 
one would expect that women with an education with a high "atrophy rate" have more childlessness than women with an education that does not depreciate as rapidly in case of employment interruption or reduced employment. ${ }^{6}$

2.2.4. Gender dominance on the job. Some educations prepare for an occupation in labor-market segments with a high share of female employees, while some others train for jobs in male-dominated occupational sectors. The latter include such areas as technology, mechanical engineering, or some natural sciences; while teaching, nursing, or personal services are usually highly feminized occupations. ${ }^{7}$ One normally assumes that employment areas with a high share of female employees provide an environment in which pregnancy and motherhood are quite common and which is therefore conducive to childbearing (see also our corresponding argument in Section 2.1.2). Female-dominated sectors usually offer high job flexibility, more part-time opportunity, and more exit and (re-)entry options. One would also assume that they hold greater promise that employers are accustomed to the needs of childrearing parents and that employment and childcare are more compatible than elsewhere. However, female-dominated areas are also areas with a low income profile, "de-regulated" working hours, non-standard, non-insured, time-limited, or other precarious work arrangements, gender-segregated career tracks, less skill and employment protection, fewer upward career possibilities, and sometimes even less compatibility with childrearing (Anker 2001; England 1982; 1984; Budig and England 2001; Hultin 2003). By contrast, male-dominated occupations typically pay comparatively higher wages, also for women, but may have time-demanding work norms or a male-dominated work environment, such as standard or longer working time, less consideration for employees' needs to give care, and often a working culture dominated by "masculinity”. All in all, we may expect less childlessness among women with an education that leads to female-dominated occupations than among women with an education that leads to male-dominated occupations. However, even some female-dominated fields

change so tremendously during the past two decades that their ,atrophy rate“ must have increased considerably.

${ }^{6}$ Depreciation effects may be counterbalanced by educational policies that offer recurrent education or retraining after employment interruption, which again highlights the role of educationalsystem flexibility. Skill depreciation may further be mitigated through family policies that discourage long employment interruptions and support job retention during early childrearing years (see Hoem, Neyer, Andersson 2005).

${ }^{7}$ The degree of feminization may vary over time and across educational levels. 
may have work conditions that make more women refrain from having children, which would lead to higher childlessness in such female-dominated areas.

\section{The Swedish educational system}

As we mentioned above, the structure and organization of an educational system may have a decisive influence on fertility outcomes. In this section we briefly sketch the main elements of the Swedish educational system, highlighting factors that are relevant for our analysis. Henz and Jonsson (2003) pick up many of the same threads as us in their concise description of the Swedish system.

In addition to promoting educational attainment, the Swedish educational system aims at furthering social equitability, encouraging recurrent education, and aligning education to the changing needs of society and labor markets (ElgqvistSaltzman 1988; Rusak 1977; Meghir and Palme 1999; Marklund 1981; BronWojciechowska 1995). To this end it has been set up as a uniform and flexible educational system with basically three levels of education, as follows. ${ }^{8}$

Primary education consists of a nine-year comprehensive and co-educational school, mandatory for all children between 7 and 16 years of age. The curriculum is largely the same for all pupils at this level.

Upper-secondary education ${ }^{9}$ is mostly directed toward pupils aged from 16 to 18 or 19 years, though Sweden has an extensive system to provide such education to individuals who "missed out" as teenagers. It is an integrated system covering both vocational and theoretical education. The curriculum is set up in a way to allow pupils to adapt their training according to their abilities and interests (Erikson and Jonsson 1996; Breen and Jonsson 2000). During the 1970s and 1980s, the period most relevant for our cohort, upper-secondary school encompassed both two-year and three-year lines. The two-year lines (which were turned into three-year lines in the 1990s) mostly accommodated vocational or semi-vocational lines of education, such as education to become an office-worker, textile worker, mechanic, electrician, or health-care worker. The three-year lines comprise academic study programs such as general education in

\footnotetext{
${ }^{8}$ The basis for this system was laid in the 1960s and 1970s. The cohort on which our empirical analysis focuses, namely women born in 1955-59, were among the first to be educated under this system. We indicate its main features during the period when most of our cohort attained their highest educational level.

${ }^{9}$ Since lower-secondary school is integrated into the compulsory primary education, the uppersecondary education is sometimes simply called secondary school.
} 
the humanities, business, or natural sciences. All three-year lines grant direct access to tertiary ("higher") education. Various extensions to and specializations following a two-year program can also produce a secondary education normed to be of three years' length. Almost all pupils continue to upper-secondary school after compulsory education (Marklund 1981, 203; Marklund and Bergendahl 1979, 13; Henz and Jonsson 2003, 238).

Higher education is given at three levels. (i) "Lower-tertiary" education is scheduled to lasts for two to three years and has a focus on advanced vocational training. Educations to become a nurse, midwife, music and arts teacher, youth worker, or laboratory assistant, to name a few, are all provided at the lower-tertiary level. (ii) "Upper-tertiary" education is scheduled to last at least three to four years and corresponds to an American undergraduate college education, going up through the B.A./B.Sc. and the M.A./M.Sc. in the Swedish case. ${ }^{10}$ Upper-tertiary education is required for, say, high-school teachers, psychologists, social workers, physicians, or lawyers. (iii) Advanced studies beyond this level lead to research degrees (Swedish licentiate and doctoral degrees), corresponding in principle to an American Ph.D. or to a continental-European research doctorate.

Higher education has also been open to students who have not acquired access through secondary education, in particular to adults with work experience (Marklund 1981, 204; Elgqvist-Salzman 1988, 494). Women and men of age 25 or more with at least four years of gainful employment have been eligible to apply to enter higher education even if they had not completed a form of secondary education that would otherwise have granted them access to higher education (Marklund 1980, 271).

Continued education and social equality in educational advancement are supported through an extensive system of adult education and through a system of financial assistance for people in education. Education for adults is offered at all levels of instruction and in various forms, for example as labor-market training, in-service training, supplementary education, or continuing education to enhance schooling in general. ${ }^{11}$ Employees have the right to take a break in employment in order to receive instruction, with a guarantee of a return to employment after the completion of education.

\footnotetext{
${ }^{10}$ The Swedish titles are different.

${ }^{11}$ See Swedish National Agency for Education (2004) at http://www.skolverket.se/english/system/index.html
} 
All students in higher education are entitled to financial assistance. ${ }^{12}$ This benefit consists in part of a grant that is not paid back, and for the main part of a loan that is repaid over 25 years or by the time when the borrower reaches age 60 (The Swedish Institute 2004; Salerno 2002, 40). During educational enrollment, employees who have interrupted their employment to continue their studies have received governmental subsidies corresponding to a high fraction of a regular salary (Marklund 1980, 205). Several other financial benefits are available for unemployed persons under re-training and for adults who want to complete upper-secondary education. The entitlement to financial study assistance is an individual right. This means that neither the parents' nor the partner's economic circumstances are taken into account when an application is considered. ${ }^{13}$

The focus on continued education and on (re-)education geared to the needs of the labor-market has two consequences. First, the share of people with no more than primary education is rather low in Sweden (Müller and Wolbers 2003). In our cohort (women born between 1955 and 1959) 18\% have primary education as their highest educational attainment. ${ }^{14}$ Slightly over half of all women has completed upper-secondary school (37\% on a two-year line and $15.5 \%$ in a three-year education), and almost one third (29.5\%) has a higher educational degree.

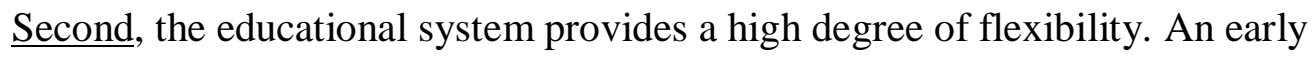
choice of educational direction does not rule out other educational possibilities later in life. The opportunities for recurrent education allow individuals to resume their education, to upgrade it, to complement it through additional study, or to change their field of education at any stage in their lives, according to their interests, abilities, motivation, work, or family needs. Although it does not happen very often, a person with a degree at a higher educational level may in principle return to take education at a lower educational level. For example, a person who has a university degree in the humanities at the "upper-tertiary" level may retrain as a youth worker, which is a "lower-tertiary" education. Education is also not segregated from adult working life. People taking upper-secondary or tertiary education commonly interrupt their studies

\footnotetext{
${ }^{12}$ The assistance is granted up to age 51, but has reduced amounts for those aged 41 and above (The Swedish Institute 2004).

${ }^{13}$ The student's own income is taken into account, however, and for very high individual incomes the amount of financial assistance is reduced (The Swedish Institute 2004).

${ }^{14}$ The share is calculated excluding the $4.8 \%$ of women whose education is not recorded in the data.
} 
for a while to work in a job and to resume their studies later (Marklund 1981, 203). A large share of the students in higher education have working experience and are over 25 years old (Marklund 1981, 204). Contrary to what may be the case in many other countries, alternating education and employment or combining part-time work with part-time education is actually the most common path through education in Sweden (ibid.; Breen and Jonsson 2000; Erikson and Jonsson 1996).

As a consequence of the flexibility of the Swedish educational system, many women continue their education during the period of childrearing. When educational enrollment extends well into a woman's fertile years and she starts to have children, it of course has considerable consequences for her educational progress, even in the most helpful of systems. Therefore, we like to see childbearing and education as dynamically interactive processes that individuals do their best to control as they go along. It is too simplistic to believe that the choice of an education is directed by clear goals which individuals set for themselves at an early age and which they subsequently pursue in a linear and cumulative manner until education is completed, after which jobs are sought and union formation as well as childbearing follows. Swedes do not always build up their educational attainment in such a monotonic manner, adding exam to exam without ever retracing their steps or changing their minds about how they want their education to be. Nor do they just leave the educational system upon completion of an education and get themselves a job and then children, never to return to take more education. Throughout the young-adult years and beyond, there is movement into and out of education. (In our companion paper we shall show how this is picked up in our data.) In this process, a woman's perceptions will be honed against the realities of educational and occupational life, and there will be a process of adaptation of the individual to life's possibilities.

Thus, "unordered" educational careers, such as interruption of education, changes in the field of studies, and resumption of studies in the same or a different field, have become a common feature of the people's pursuit of education in Sweden (Breen and Jonsson 2000, 758). Viewing education, work, and childbearing together, we find that what Rindfuss et al. (1987) and Jonsson (2001) have called "disorder of the life-course" is the order of the day in Sweden.

The aim to achieve equality in educational opportunity in Sweden has led to a decline in the effect of gender on overall educational attainment (Shavit and Blossfeld 1996, 238f.). The differences between men and women in educational attainment have 
decreased, and for some educational levels even reversed (Elgqvist-Saltzmann 1988, 495; Stanfors 2003,$74 ; 153)$. Nevertheless, women tend to choose shorter educational lines than men do, so that a gender gap remains at more advanced educational levels.

Despite the increase in the share of women in secondary and tertiary education, gender segregation by field of education persists (Stanfors 2003, 78, Table 4.3). Women constitute the vast majority of upper-secondary graduates in personal care, health care, arts, social sciences, and business and administration, but only a minority in science and technology (Stanfors 2003, 254, Table A8.18). At the tertiary level, women largely outnumber men in the areas of health, teaching, arts, and humanities, but they are less well represented in technology and the natural sciences (ElgqvistSaltzmann 1988, 496). The gender gap seems to be less pronounced in such areas as law and social sciences. However, within these broad fields of study, the gender distribution varies greatly. In the social sciences, for example, women crowd into areas like social work while they make up only about half of the graduates in law. In teaching, women dominate the study lines of primary-school teaching, education for children with special needs, or child- and youth pedagogics, but they do not outnumber men in education for upper-secondary teaching. In the technical and natural sciences, women choose study lines like druggist, pharmacist, or veterinarian, or study to become professionals in the natural sciences, and they opt less often for civil engineering or for engineering in general (Elgqvist-Saltzmann 1988, 496; Statistics Sweden 1997, 375ff.). On the whole, programs designed to break gender-stereotyping in educational choice have worked asymmetrically; girls and women have entered science and technology to a greater extent than boys and men have taken to female-dominated educations (Stanfors 2003). Therefore, if we look at broad subject categories, girls and women (in secondary and tertiary educations) have come to display a wider spectrum of subject choices than boys and men do, but the gender pattern of educational fields nevertheless remains pronounced.

\section{Main results}

4.1. Main features. Figure 1 contains our main results on permanent childlessness among women in our selected cohort, namely the one born in Sweden in 195559. The diagram is based on the information in Table A2 (see Appendix 2). We operate with close to sixty educational groups in that table, and have written the name of 
a selection of them into the diagram. We have indicated the various fields of education by markers of various forms and colors.

[Figure 1 about here]

Like most others, we find lower fertility (in this case higher permanent childlessness) to be associated with more education for women, but in our data this only holds in each educational field. The trend-lines included in the diagram for selected educational fields and over the various educational levels illustrate this. An equally important feature of the diagram is, however, that the educational orientation is at least as important as the level attained. For instance, and to start of with some contrasting examples, women who have completed no more than primary school or lower secondary school have a similar level of childlessness (14.7\%) as teachers of children with special needs $(14.1 \%)$, home-economics teachers $(14.3 \%)$ or physicians $(15.9 \%)$ do, all of which have a higher tertiary education. The same holds for women who have an education as cleaners (15.5\%), mail carriers (14.7\%), typists and office assistants (14.7\%), or technical and mechanics assistants (15.2\%) in industry, crafts and engineering. Women who are trained in personal services in the hotel and restaurant business, as grand-household administrators, or in general service, all of whom have an education at the two-year secondary level, have even higher childlessness $(21.5 \%$ to $22.4 \%$ ) than physicians (15.9\%), high-school teachers (17.3\%) and medical doctors with a research degree (18.9\%) do. They equal the level of childlessness among women with a higher-tertiary degree in the social sciences $(22.1 \%)$, journalism (22.2\%), business administration (21.3\%), pharmacy (20.9\%), psychology (20.7\%), and the natural or technical sciences $(20.2 \%)$.

In general, we find that women educated for jobs in teaching and health care are in a class of their own, with much lower permanent childlessness than in any other major grouping at each educational level (rate of childlessness among all women with an education in health care: $10.8 \%$, in teaching: $12.5 \%$; average among all women: $15.7 \%)$.

Women educated as librarians, artists, humanists, and theologians have much higher childlessness (27.3\%) than any other group. In this connection, humanists are women who have a university education in the liberal arts, but who have not acquired qualifications to be a high-school teacher (namely mostly training in didactics). 
Women with a corresponding background and teaching qualifications are assigned to the group educated to be high-school teachers and have significantly lower childlessness (humanists: 30.4\%; high-school teachers: 17.3\%). Women who received a (lower- or higher-)tertiary degree in theology also remain childless quite often (27$31 \%$ childless). Our companion study on ultimate fertility (Hoem, Neyer, and Andersson 2005) reveals that among women with an education in theology, there seems to be a bifurcation between women who remain childless and women who have a comparatively large number of children.

Women with an education in administration, business, law, and the social sciences have on average a similar rate of childlessness (16.9\%) as women with an education in industry, crafts, engineering, and the natural and technical sciences do $(16.5 \%)$. But there are more sub-categories of educational fields in administration, business, law, and social science in which women show higher rates of childlessness (20\% and above) than in industry, crafts, engineering, and the natural and technical sciences.

The pattern of childlessness by educational fields shows that the educational level is not sufficient to make inferences about the relationship between education and fertility levels. It may even lead to wrong assumptions about education and childlessness. The educational field is a much better indicator of permanent childlessness than the educational level. Nevertheless, the pattern of childlessness by educational fields does not alone provide a straightforward answer to the question how education and fertility are interrelated. Individual factors and institutional factors seem to intertwine in bringing about the pattern of childlessness that we observe. We will return to this issue in more detail when we discuss our findings below.

We highlight some of these features further in the following subsections.

4.2. Childlessness and mean age at completion of education. One may perhaps expect higher childlessness among groups that complete their education relatively late, and to some degree Figure 2 bears this out. However, as with the association between educational level and childlessness, this applies primarily to educations in the same field. Even within a field of education we do not always find that longer education leads to higher childlessness. This may be partly attributed to the character and flexibility of the Swedish educational system. Several of our educational categories 
are second educations or educational extensions, so there is no clear causal relation between recorded age at completion and entry into motherhood. Perhaps the most interesting feature of Figure 2 is what it tells us about the timing of educational completion in Sweden. We notice that on average women take their doctorates at a relatively advanced age (namely in their mid-thirties), and that master's degrees in psychology and social science are completed around age 33 on the average. We are not sure why the latter groups take so much longer than other academics to complete their master-level studies, but we suspect that for many students, psychology may be a continued education after some previous line of study or that many students of psychology pursue some clinical or therapeutic training, which may prolong their studies. Women educated as teachers for children with special needs are in a similar category, in that such an education typically is taken as a later specialization by people who already are qualified teachers. (The education as a "special-education teacher" was completed at age 34.5 on average in our cohort.). Similarly, education as a deaconess often succeeds some other previous training. Some educations require previous degrees, the way all higher university degrees do. To become accepted into a program for midwifery, a woman needs to be an accredited nurse. Such requirements explain, why midwife certificates are attained as late as at age 30 on average.

[Figure 2 about here]

4.3. Outliers. Some educational groups appear to be essentially different from others in terms of childlessness. Here are some that have struck us.

\subsubsection{Outliers 1: Groups with more than a quarter childless. Women educated} in arts and humanities and for religious occupations have unusually high fractions permanently childless. As we shall see below, women with a religious education do not have particularly high percentages never married, quite on the contrary. ${ }^{15} \mathrm{We}$ suppose that some particular selection process is involved. So much childlessness is particularly remarkable for women with a brief religious education, who often become deaconesses. Despite the fact that a high fraction of women educated in theology work in the field in which they are trained (Ahola 1999, 26), about a third go into

\footnotetext{
${ }^{15}$ We would expect theologians and others with a religious education to confine even their first childbearing to marriage, which is hardly the case for most other educational groups in Sweden.
} 
other occupations. Deaconesses often go to occupations in the care and charity sector or into youth work. Other women with an education that lead to similar occupations (such as nurses or educated youth workers) have low fractions childless. We shall return to these educational groups when we study their ultimate number of children in our companion paper (Hoem, Neyer, and Andersson 2005).

One might speculate that an education which does not lead to a regular and rather predetermined occupation might entail a more uncertain life, something that could make it less compatible with childbearing than other types of education. This may be true for our artists and (non-teaching) humanists, whose education often leads to free-lance work, but this line of reasoning hardly fits librarians, who also have unusually high fractions childless despite the fact that their education is a direct preparation for their normal occupation. On the other hand, artists, humanists, deaconesses, and librarians have a relatively low mean annual income compared to other women on the same educational level, and this may be a disincentive to have a child. (For references showing how low earnings are associated with reduced entry into motherhood among Swedish women, see Hoem 2000, Andersson 2000.) Weak earnings alone do not seem to work toward increased childlessness, however, as we see if we bring other educational groups into the picture. Women with an education as cleaners, service workers, or beauticians, for example, have mean annual incomes that are lower than or equal to artists, humanists, or librarians, but these less highly educated groups do not have anywhere as high fractions childless. We assume that a perception of relative deprivation may play a role. Librarians (say) may possibly compare their own incomes with other women with a tertiary education rather than with less highly educated service personnel and adjust their childbearing accordingly, but we suspect that there is some further explanation that goes beyond what we can see in our data (or otherwise in the empirical literature).

\subsubsection{Outliers 2: Groups that never marry. We believe that marriage forma-}

tion is only a partial determinant of childbearing in Sweden. In 1980, when our cohort was between 21 and 25 years old, almost $40 \%$ of all births were out of wedlock; the rate increased to almost $50 \%$ by 1985 , and it had gone beyond $50 \%$ by 1995 (Council of Europe 1999, 67). Nevertheless we have plotted the per cent childless in our educational groups against the per cent never married in Figure 3 out of pure curiosity. The stippled segmenting line indicates where the two percentages add up to 45 , and 
we have drawn it because it seems to largely separate the educational groups into recognizable clusters, much as the famous Hajnal line separated the countries in Europe by dominant family types (Hajnal 1965). Evidently, groups educated for teaching or health provision have both low percentages never married and low percentages childless. Education for administrative, economic, and social-science occupations scores notably higher on both dimensions. The religiously educated form a group for themselves, with low percentages never married (around 20\%) and high percentages childless (almost 30\%), manifesting another aspect of the bifurcation that we mentioned earlier. The artists, humanists, and librarians end up with high percentages on both counts; note how they spread around the forty-percent-point never married.

[Figure 3 about here]

4.3.3. Non-outliers: Women with research degrees. Swedish women with research degrees (licentiates or doctorates) end up completing their degrees in their midthirties on average. They tend to have fractions childless on the high side for their line of education, but otherwise do not appear systematically different from other women. This is all the more remarkable as both economic and culture-based theories would lead us to expect particularly high fractions childless among these most highly educated women. In our eyes, this finding (and the corresponding finding about their ultimate number of children in the companion paper) throws considerable doubt on both types of theory.

\section{Reflections on our main findings}

After the foregoing description of the patterns that have struck us most prominently in our findings, we now confront our theories in the previous sections with our empirical findings.

5.1. The gender structure of the educational system. The low rate of childlessness among women with an education in health, care, and teaching ${ }^{16}$ gives some support to the hypothesis that a high share of women in an educational line leads to lower childlessness. In Sweden, as in many other countries, women make up the vast majority of all upper-secondary graduates in health care and in child recreation, and of the

\footnotetext{
${ }^{16}$ Music and arts teachers excepted; we count these groups together with artists.
} 
higher-education students and graduates in health-related educations (about 85-90\% in each group, medical science excepted) as well as in teaching (75-80\%). ${ }^{17}$ Women dominate the study lines for child- and youth pedagogies (pre-school and after-school teaching), education for children with special needs, and also home economics (more than $90 \%$ of all students and graduates in each case; Statistics Sweden 1997, 375f.). All of these groups have rather low rates of childlessness. We find a similar association between a clear female dominance and low rates of ultimate childlessness in several other educational fields, such as education for work with textiles and clothes production (about $95 \%$ women) or pharmacy receptionists (91\% women).

The association is less convincing in fields of education with a more mixed gender distribution, that is where women make up about $40 \%$ to $66 \%$ of the students or graduates, or in fields of education where women are a minority (below $40 \%$ of graduates). For example, women constitute about $66 \%$ of the graduates from the humanities; in law and the social sciences they comprise 55\%; and in the fine arts and medical sciences about 50-52\%. Contrary to what one would perhaps expect from the gender-dominance argument, childlessness in these groups is highest among humanists and lowest among physicians. Moreover, there is a big discrepancy in the level of childlessness between physicians and women with a degree in the fine arts, despite the fact that both study in environments with similar gender distributions. In our eyes, selectivity mechanisms are at work, combined with differences in working conditions for the various groups.

Similarly, there are about as many women as men among the upper-secondary graduates in food processing and in the hotel and restaurant business, but their rates of childlessness differ considerably (food processing: 14.0\%, hotel and restaurant workers: $22.4 \%$ ). Women with an education in technology and engineering, where graduates are less than $25 \%$ female, have almost as much childlessness as women with an education in business and administration, where somewhere between half and two-thirds of the graduates are women.

Thus, on the whole, a higher share of women in an educational field does not lead systematically to lower childlessness, unless women outnumber men at a ratio

\footnotetext{
${ }^{17}$ These statistics refer to the period from the mid-1970s to the end of the 1980s. They thus roughly represent the time when most of the women in our cohort took their education. Such rates have not changed much since. Sources: Stanfors 2003, p. 78, Table 4.3; and pp. 256-257, Table A8.20, our calculations. See also Statistics Sweden 1997, pp. 366-370 and 375f., Table 4.26.
} 
above three-to-one. The level of childlessness among women who took an education in a field with a mixed gender structure (social science, humanities, arts, personal services, business and administration, law) varies markedly. For women with a tertiary education we even find that on average women with a degree in a male-dominated field (where there is less than $25 \%$ women, as in some natural sciences and in technology) may display lower childlessness than women in a field with a more gender-equal student body (as in the humanities, arts, law, pharmacy). Evidently, fertility outcomes are not a simple matter of "the higher the share of women, the lower the childlessness"; an explanation of childlessness must be multidimensional.

5.2. Education and the labor market. We can group educations into five broad clusters according to the labor-market and employment situations they most often lead to. The levels of childlessness only vaguely reflect the expectations we voiced in Section 2.2.

\subsubsection{Education leading to a reliable employment career in the public sector.}

First, women educated in health, care, and teaching have chosen educational lines with a rather calculable future employment career, and they also have the lowest level of childlessness, as we have noted several times already. Most women educated in one of these fields are employed in the area in which they are trained in; they work in highly feminized occupations and in the public sector (Melkas and Anker 1998, 14; Statistics Sweden 1997, 173f; Ahola 1999; Smyth 2003). As we pointed out earlier, the public sector offers greater employment security, stable income prospect, more flexible work-time opportunities, and higher parental-leave benefits ${ }^{18}$ than the private sector normally does, and the public sector is therefore the more conducive to childbearing and childrearing. However, as the higher level of childlessness among women who also work in the public sector, but are educated to be music and arts teachers, librarians, or pharmacy employees ${ }^{19}$ shows, public-sector employment or female domination do not in themselves lead to lower childlessness.

\footnotetext{
${ }^{18}$ Public sector employers usually grant additions to the parental-leave benefit so that public-sector employees receive essentially full income compensation during parental leave. By law, the parental-leave benefit in Sweden currently amounts to $80 \%$ of a person's previous income (up to a certain high level).

${ }^{19}$ Pharmacies in Sweden are state owned.
} 
5.2.2 Highly feminized occupations in the private sector. Our second cluster comprises educational lines that lead to highly feminized occupations in the private sector. Such areas comprise a wide range of educational fields, among them food processing, textile work, beauticians and hairdressers, and service in hotel and restaurant businesses. The spectrum of educational-occupational dissimilarity (that is the range of jobs that the women hold that do not match what they were trained in) is somewhat wider than in the area of health, care, and teaching. In declining industrial fields, such as textile work, the job-mismatch may be even larger (Ahola 1999). But depreciation of education during employment breaks is often lower than in the health professions. The rate of childlessness in these areas seems to depend on the working conditions, including how precarious job contracts tend to be. Not surprisingly, women who chose an education that leads to occupations with time-demanding working conditions (long or odd working hours) and high employment mobility, such as the hotel and restaurant business, have higher levels of childlessness than other women.

\subsubsection{Gender-mixed educational lines with little occupation-specificity. Our} third educational cluster consists of gender-mixed educational lines that are not really directed to any specific occupation. This group includes women who leave the educational system after primary school or after a general upper-secondary education without a real vocational component. It also comprises education in the humanities, fine arts, or general social science. Women with such a background face greater difficulties than others in their transition to the labor market (Korpi, de Graaf, Hendrickx, and Layte 2003) and they end up in very diverse jobs, such as in clerical work at various levels, in libraries, schools, general administration, and so on (Ahola 1999, 27f.). Childlessness is moderate to high among these women.

\subsubsection{Gender-mixed educational lines with high occupation-specificity. By} contrast, our fourth cluster encompasses gender-mixed educational lines that offer an occupation-specific education and qualify for jobs with varying employment prospects and varying returns, such as education in business and administration, journalism, or law. In these areas childlessness is generally higher than average, just as in the previous group. The degree of occupation-specificity must matter less than other aspects of education. 


\subsubsection{Male-dominated lines of education. Our fifth and final cluster covers} male-dominated lines of education; they mostly lead to private-sector employment. This mainly comprises education in technology, engineering, and the natural sciences. Women with an education in these fields face a longer job-search process after education; they are less likely to obtain a first job with employment security (in their respective field) and their possibilities to maintain employment is lower than in other fields of education (Smyth 2003, 66f.; he argues that there is a second segregation at the level of occupations). Nevertheless, these women surprisingly have low childlessness. $^{20}$

5.3. Selection and adaptation. After the above eyeballing of the facts, we feel that the theories we reviewed cannot explain the relationship between of educational orientation and subsequent childlessness completely. Obviously, the fraction permanently childless in an educational group must be the outcome of many processes that function in interaction with each other. We may need to evoke the demographers' age-old concepts of selection and adaptation (Goldman 2001). There seems to be a process of selection of women into fields of education, steered both by individual abilities, interests and preferences (Hakim 2000), and by social and normative pressures. Social background, the structure of the educational system, and norms and conventions concerning what kind of education and what ensuing occupations are suitable for a woman each play a role in this process. ${ }^{21}$ The type and level of education a woman successively attains are determinants of her employment, her income security, her work environment, and her career opportunities, and then also of her reproductive behavior. Since we may assume that (at least to some extent) there is a purposive element in most people's decisions, these considerations presumably work both ways, so

\footnotetext{
${ }^{20}$ Note that women with a mechanic's education have one of the highest fractions never-married, nevertheless they have very low childlessness.

${ }^{21}$ Many studies (e.g.: Jonsson 1999; Breen and Jonsson 2000; Dryler 1998 ) show how important a girl's social environment is in her "choice" of field of education. Jonsson $(1999,400)$ shows that although Swedish pupils' perception of their "comparative advantage" (that is, of their talents and achievements in relation to others) is important for the selection of the line of education (at the secondary level), it does not explain the substantial sex-segregation in the choice of educational programs. The classroom composition and family background constitute a major factor in the choice of subject lines. Our study suggests that considerations about future professional and family life may also have an impact on the choice of the field of education.

In principle, educational opportunities may play a further role, in that a free choice of education may not be available to all women at all times, though the latter issue should perhaps not be so important in advanced industrialized countries in recent decades.
} 
a woman's evolving perception about the kind of life an education may lead to is an active element in her decision process. We may therefore expect a dynamic interaction between a woman's educational path, her childbearing plans, and her actual childbearing.

\section{Education and fertility - some implications for future research}

The results of our study have several implications for demographic research. Clearly, better than the mere level of education, the field of education can additionally serve as an indicator of a woman's potential reproductive behavior. Therefore, one conclusion is obvious: In studies of the impact of education on fertility, the representation of educational attainment needs to reflect much more than just the level attained. Adding educational orientation will at least give us a proxy for underlying features connected to education that have an influence on entry into motherhood. Undoubtedly we also need to identify which underlying features associated with education influence fertility behavior and how. This requires paying attention to the context in which education is provided and thus considering the institutional aspects of education, that is, the structure and organization of education. Moreover, we need to take into account that for many fields of education the labor-market sector in which a woman will work is largely predetermined. It seems that for some groups of women the choice of the educational line may be influenced by considerations regarding the potential compatibility of employment and childbearing. ${ }^{22}$ We therefore should include institutional aspects of labor markets that reflect the different conditions under which women with different educations work. Whether one can get data on such features or not, they are likely to have consequences for the childbearing patterns that the statistician can observe, and they must be taken into account when observed patterns are interpreted. On the whole, the results of our study suggest that the choice of education does not only mirror a woman's interests, her preferences, her talents, her background, or her professional and economic aspirations, but it also reflects her considerations regarding her potential childbearing plans - however vague such plans may be at the time in life when the decisions about the line of education are made. As a consequence, education cannot be merely viewed as an economic or human-capital

\footnotetext{
${ }^{22}$ This would partly explain the persistence of gender segregation in educational systems, in particular in countries where specific fields of education lead to employment in sectors with better opportunities to combine childbearing and employment.
} 
indicator, but its impact on fertility needs to be analyzed within an institutional framework that considers the relationship between education, labor market, state, and family. Our analysis pinpoints where one should start to look, but it is evident that we are only beginning to discern some of the reasons why groups of women remain permanently childless.

\section{Acknowledgements}

The project from which this report is a product, builds on an idea by Britta Hoem to study the link between educational orientation and fertility. She published some of her results (Hoem, 1994) but left most of them unpublished except in an internal report (Hoem and Hoem, 1995). We have benefited from comments to presentations made in Lund, Sweden (11 November 2002), in Rostock, Germany (31 January 2003), and in Münster, Germany (9 October 2003). We are grateful to Statistics Sweden for making the data available to us and for explaining many details about the Swedish educational register.

Jonathan MacGill cleaned the data for us and did the programming to produce the tables on which we have based our analysis. We are also grateful to Kirsten Bohne, Esther Geisler, Silvia Leek, Dorothea Rieck, and Anke Schwarz for research assistance. 


\section{References}

Ahola, Sakari (1999). The matching of educational and occupational structures in Finland and Sweden. Final Report. CEDEFOP (European Centre for the Development of Vocational Training). Thessaloniki.

Allmendinger, Jutta (1989). Career mobility dynamics. A comparative analysis of the United States, Norway, and West Germany. Studien und Berichte 49, MaxPlanck-Institut für Bildungsforschung, Berlin.

Andersson, Gunnar (2000). The impact of labor-force participation on childbearing behavior: Pro-cyclical fertility in Sweden during the 1980s and the 1990s. European Journal of Population 16 (4), 293-333.

Anker, Richard (2001). Theories of occupational segregation by sex: An overview. In: Loufti, Martha Fetherolf (ed.). Women, Gender and Work. What is equality and how do we get there? International Labour Office, Geneva, 129-155 (first published in: International Labour Review 136 (3), 1997).

Becker, Gary S. (1960). An economic analysis of fertility. In: National Bureau of Economic Research (ed.). Demographic and Economic Change in Developed Countries. A conference of the universities-national bureau committee for economic research. Princeton University Press, Princeton, 209-240.

Becker, Gary S. (1981). A Treatise on the Family. Harvard University Press, Cambridge, Mass.

Benner, Mats and Torben Bundgaard Vad (2000). Sweden and Denmark. Defending the welfare state. In: Scharpf, Fritz W. and Vivien A. Schmidt (eds.). Welfare and work in the open economy. Volume II. Diverse responses to common challenges. Oxford University Press, Oxford, 399-466.

Bernardi, Laura (2003). Channels of social influence on reproduction. Population Research and Policy Review 22 (85), 527-555.

Blossfeld, Hans-Peter and Johannes Huinink (1991). Human capital investment or norms of role transition? How women's schooling and career affect the process of family formation. American Journal of Sociology 97 (1), 143-168.

Blossfeld, Hans-Peter and Ursula Jaenichen (1992a). Bildungsexpansion und Familienbildung. In: Diekmann, Andreas and Stefan Weick (eds.). Der Fami- 
lienzyklus als sozialer Prozeß. Bevölkerungssoziologische Untersuchungen mit den Methoden der Ereignisanalyse. Duncker \& Humblot, Berlin, 165-193.

Blossfeld, Hans-Peter and Ursula Jaenichen (1992b). Educational expansion and changes in women's entry into marriage and motherhood in the Federal Republic of Germany. Journal of Marriage and the Family 54, 302-315.

Blossfeld, Hans-Peter and Andreas Timm (eds.) (2003a). Who marries whom? Educational systems as marriage markets in modern societies. European Studies of Population, Vol. 12. Kluwer Academic Publishers, Dordrecht.

Blossfeld, Hans-Peter and Andreas Timm (2003b). Educational systems as marriage markets in modern societies. A conceptual framework. In: Blossfeld, HansPeter and Andreas Timm (eds). Who marries whom? Educational systems as marriage markets in modern societies. European Studies of Population, Vol.

12. Kluwer Academic Publishers, Dordrecht, 1-18.

Boucher, Leon (1982). Tradition and change in Swedish Education. Pergamon Press, Oxford.

Bradley, Karen (2000). The incorporation of women into higher education: Paradoxical outcomes? Sociology of Education 73 (1), 1-18.

Breen, Richard and Jan O. Jonsson (2000). Analyzing educational careers: A multinominal transition model. American Sociological Review 65 (5), 754-772.

Bron-Wojciechowska, Agnieszka (1995). Education and gender in Sweden. Is there equality? Women's Studies International Forum 18 (1), 51-60.

Budig, Michelle J. and Paula England (2001): The wage penalty of motherhood. American Sociological Review 66, 204-255.

Charles, Maria and Karen Bradley 2002. Equal but separate? A cross-national study of sex segregation in higher education. American Sociological Review 67 (4), 573-599.

Charles, Maria (2003). Deciphering sex segregation. Vertical and horizontal inequalities in ten national labor markets. Acta Sociologica 46 (4), 267-287.

Cigno, Alessandro. Economics of the Family. Clarendon Press, Oxford 1991. 
Council of Europe (1999). Recent demographic developments in Europe. Council of Europe Publishing, Strassbourg.

Dausien, Bettina (1999). Geschlechtsspezifische Sozialisation - Konstruktiv(istisch)e Ideen zur Karriere und Kritik eines Konzepts. In: Dausien, Bettina et al (eds.): Erkenntnisobjekt Geschlecht. Feministische Perspektiven verwandeln Wissenschaft. Leske \& Budrich, Opladen, 216-246.

DeGraff, Deborah S. and Richard Anker (1999). Gender, labour markets and women's work. International Union for the Scientific Study of Population, Liège.

Dorbritz, Jürgen (2003). Polarisierung versus Vielfalt. Lebensformen und Kinderlosigkeit in Deutschland - eine Auswertung des Mikrozensus. Zeitschrift für Bevölkerungswissenschaft 28 (2-4), 403-421.

Drew, Eileen and Ruth Emerek (1998): Employment, Flexibility and Gender. In: Drew, Eileen; Ruth Emerek, and Evelyn Mahon (eds). Women, Work and the Family in Europe. Routledge, London, 89-99.

Dryler, Helen (1998). Parental role models, gender and educational choice. The British Journal of Sociology 49 (3), 375-398.

Dryler, Helen (1999). The impact of school and classroom characteristics on educational choices by boys and girls. Acta Sociologica 42, 299-318

Elgqvist-Saltzman, Inga (1988): Educational reforms - women's life patterns: A Swedish case study. Higher Education 17, 491-504.

England, Paula (1982). The failure of human capital theory to explain occupational sex segregation. The Journal of Human Resources 17 (3). 358-370.

England, Paula (1984). Wage appreciation and depreciation. A test of neoclassical economic explanations of occupational sex segregation. Social Forces 62 (3), 726-749.

England, Paula, George Farkas, Barbara Stanek Kilbourne, and Thomas Dou (1988). Explaining occupational sex segregation and wages: Findings from a model with fixed effects. American Sociological Review 53 (4), 544-558. 
Erikson, Robert and Jan O. Jonsson (1996). Can education be equalized? The Swedish case in comparative perspective. Westview Press, Boulder, Co.

Erikson, Robert and Jan O. Jonsson (2003). Qualifications and allocation process of young men and women in the Swedish labour market. In: Shavit, Yossi and Walter Müller (eds.). From school to work. A comparative study of educational qualifications and occupational destinations. Oxford University Press, Oxford, 369-406.

Estevez-Abe, Margarita; Torben Iversen, and David Soskice (2001). Social Protection and the Formation of Skills: A Reinterpretation of the Welfare State. In: Hall, Peter A. and David Soskice (eds.). Varieties of Capitalism. The Institutional Foundations of Comparative Advantage. Oxford University Press, Oxford, 145-183.

Gangl, Markus (2003a). Returns to education in context: individual education and transition outcomes in European labor markets. In: Müller, Walter and Markus Gangl (eds.). Transitions from Education to Work in Europe. The Integration of Youth into EU Labour Markets. Oxford University Press, Oxford, 156-185.

Gangl, Markus (2003b). The only way up? Employment protection and job mobility among recent entrants to European labour markets. In: Kogan, Irene and Walter Müller (eds.). School-to-work Transitions in Europe: Analyses of the EU LFS 2000 Ad Hoc Module. Mannheimer Zentrum für Europäische Sozialforschung, Mannheim, 121-150.

Gildemeister, Regine and Angelika Wetterer (1992). Wie Geschlechter gemacht werden. Die soziale Konstruktion der Zweigeschlechtlichkeit und ihrer Reifizierung in der Frauenforschung. In: Knapp, Gudrun-Axeli and Angelika Wetterer (eds.). Traditionen Brüche. Entwicklungen feministischer Theorie. Forum Frauenforschung, Band 6. Kore Verlag, Freiburg, 201-254.

Goldman, Noreen (2001). Mortality differentials: selection and causation. In: Smelser, Neil J. and Paul B. Baltes (eds.). International Encyclopedia of the Social and Behavioral Sciences 15, 10068-10070.

Grünheid, Evelyn (2004). Junge Frauen in Deutschland: bei hoher Ausbildung kinderlos? Psychosozial 95 (1), 35-46. 
Gustafsson, Siv (2001). Optimal age at motherhood. Theoretical and empirical considerations on postponement of maternity in Europe. Journal of Population Economics 14, 225-247.

Hajnal, John (1965). European marriage patterns in perspective. In: Glass, David V. (ed.). Population in history: essays in historical demography. Edward Arnold, London, 101-143.

Hakim, Catherine (2000). Work-lifestyle Choices in the 21st Century. Preference Theory. Oxford University Press, Oxford.

Henz, Ursula (2001). Family formation and participation in higher education: crosscutting life events? In: Jonsson, Jan O. and Colin Mills (eds.). Cradle to grave. Life-course change in modern Sweden. Sociologypress, Durham, 45-69.

Henz, Ursula and Jan O. Jonsson (2003). Who marries whom in Sweden? In: Blossfeld, Hans-Peter and Andreas Timm (eds.). Who marries whom? Educational systems as marriage markets in modern societies. European Studies of Population, Vol. 12. Kluwer Academic Publishers, Dordrecht, 235266.

Hobcraft, John and Kathleen Kiernan (1995). Becoming a parent in Europe. Welfare State Program Discussion Paper Series No. 116. Suntory and Toyota International Centres for Economics and Related Disciplines, London.

Hoem, Britta (1994). Lärare föder färre barn. Välfärdsbulletinen 33, 17-19.

Hoem, Britta, (2000). Entry into motherhood in Sweden: the influence of economic factors on the rise and fall in fertility, 1986-1997. Demographic Research [Online] 2. Available http://www.demographic-research.org/Volumes/Vol2/4.

Hoem, Britta and Jan M. Hoem (1995). Education and ultimate fertility: patterns for Swedish women born in the 1940s. Internal Report from the Max Planck Institute for Demographic Research, Rostock.

Hoem, Jan M.; Gerda R. Neyer, and Gunnar Andersson (2005). Education and ultimate fertility: patterns among Swedish women born in 1955-59. Mimeo, Max Planck Institute for Demographic Research, Rostock.

Hoem, Jan M. (1997). Educational gradients in divorce risks in Sweden in recent decades. Population Studies 51, 19-27. 
Huinink, Johannes (2002). Polarisierung der Familienentwicklung in europäischen Ländern im Vergleich. In: Schneider, Norbert F. and Heike Matthias-Beck (eds.). Elternschaft heute. Gesellschaftliche Rahmenbedingungen und individuelle Gestaltungsaufgaben. Leske \& Budrich, Opladen, 49-73.

Hultin, Mia (2003). Some take the glass elevator, some hit the glass ceiling? Work and Occupation 30 (1), 30-61.

Jacobs, Jerry A. (1996). Gender inequality and higher education. Annual Review of Sociology 22, 153-185.

Jönsson, Ingrid (1999). Women and education in Europe. International Journal of Contemporary Sociology 36 (2), 144-162.

Jonsson, Jan O. (1987). Class Origin, Cultural Origin, and Educational Attainment: The Case of Sweden. European Sociological Review 3 (3), 229-242.

Jonsson, Jan O. (1999). Explaining gender differences in educational choice: An empirical assessment of a rational choice model. European Sociological Review 15, 391-404.

Jonsson, Jan O. (2001). Towards a post-Fordist life-course regime? Generational changes in transitions and volatility. In: Jonsson, Jan O. and Colin Mills (eds.). Cradle to grave. Life-course change in modern Sweden. Sociologypress, Durham, 1-28.

Jonsson, Jan O. and Colin Mills (1993). Social class and educational attainment in historical perspective: A Swedish-English comparison. Part 1. The British Journal of Sociology 44 (2), 213-247.

Jonsson, Jan O. and Colin Mills (1993). Social class and educational attainment in historical perspective: A Swedish-English comparison. Part 2. The British Journal of Sociology 44 (3), 403-428.

Jonsson, Jan O. and Colin Mills (eds.) (2001). Cradle to grave. Life-course change in modern Sweden. Sociologypress, Durham.

Kanter, Rosabeth Moss (1977a). Men and Women of the Cooperation. Basic Books, New York. 
Kanter, Rosabeth Moss (1977b). Some effects of proportions of group life: Skewed sex ratio and responses to token women. The American Journal of Sociology $82(5), 965-990$.

Kiernan, Kathleen (1989). Who remains childless? Journal of Biosocial Science 21, 387-398.

Kogan, Irena and Walter Müller (eds.) (2003). School-to-Work Transitions in Europe: Analyses of the EU LFS 2000 Ad Hoc Module. Mannheimer Zentrum für Europäische Sozialforschung. Mannheim.

Konietzka, Dirk (2002). Die soziale Differenzierung der Übergangsmuster in den Beruf. Kölner Zeitschrift für Soziologie und Sozialpsychologie 54 (4), 645673.

Korpi, Tomas; Paul de Graaf; John Hendrickx, and Richard Layte (2003). Vocational training and career employment. Precariousness in Great Britain, the Netherlands and Sweden. Acta Sociologica 46 (1), 17-30.

Kravdal, Øystein (2001). The high fertility of college educated women in Norway. An artifact of the separate modeling of each parity transition. Demographic Research 5 (6). Available at http://www.demographic-research.org/

Kravdal, Øystein (2004). An Illustration of the Problems Caused by Incomplete Education Histories in Fertility Analyses. In: Andersson, Gunnar and Gerda Neyer (eds.). Contemporary Research on European Fertility: Perspectives and Developments. Demographic Research, Special Collection 3 (6). Available at http://www.demographic-research.org/

Lappegård, Trude (2001). Valg av utdanning - valg av livsløp? Utdanning og ulikhet i kvinners fruktbarhetsatferd. Tidsskrift for samfunnsforskning 2001 (3), 409435.

Lappegård, Trude (2002). Education attainment and fertility pattern among Norwegian women. Statistics Norway, Documents 2000/18.

Lappegård, Trude and Marit Rønsen (2005). The multifaceted impact of education on entry into motherhood. European Journal of Population, forthcoming. 
Lestaeghe, Ron (1983). A century of demographic and cultural change in Western Europe: An exploration of underlying dimensions. Population and Development Review 9 (3), 411-435.

Marburger Forschungsstelle für Vergleichende Erziehungswissenschaften (1977). Kommentierte Bildungsstatistik: Schweden. Marburg.

Marini, Margaret Mooney (1984). Women's educational attainment and the timing of entry into parenthood. American Sociological Review 49 (4), 491-511.

Marklund, Sixten (1980). New stages in education: A Swedish viewpoint. Comparative Education 16 (3), 267-274.

Marklund, Sixten (1981). Education in a post-comprehensive era. British Journal of Educational Studies 29 (3), 199-208.

Marklund, Sixten and Gunnar Bergendal (1979). Trends in Swedish Educational Policy. The Swedish Institute, Uppsala.

Meghir, Costas and Mårten Palme (1999). Assessing the effect of schooling on earnings using a social experiment. Stockholm School of Economics Working Paper No. 313. http://ssrn.com

Melkas, Helinä and Richard Anker (1998). Gender equality and occupational segregation in Nordic labour markets. International Labour Office, Geneva.

Melkas, Helinä and Richard Anker (2001). Occupational segregation by sex in Nordic countries: An empirical investigation. In: Loufti, Martha Fetherolf (ed.). Women, Gender and Work. What is equality and how do we get there? International Labour Office, Geneva, 189-213 (first published in International Labour Review 136 (3), 1997).

Mincer, Jacob and Haim Ofek (1982). Interrupted work careers: depreciation and restoration of human capital. Journal of Human Resources 17, 3-24.

Mincer, Jacob and Solomon Polachek (1974). Family investments in human capital. Journal of Labour Economics 82 (2), March/April, 76-108.

Ministry of Education and Science and the National Agency of Education (2001): The development of education. National Report of Sweden. Stockholm: http://www.ibe.unesco.org/International/ICE/natrap/Sweden.pdf 
Müller, Walter and Markus Gangl (eds.) (2003). Transitions from education to work in Europe. The integration of youth into EU labour markets. Oxford University Press, Oxford.

Müller, Walter and Maarten H.J. Wolbers (2003). Educational attainment in the European Union: Recent trends in qualification patterns. In: Müller, Walter and Markus Gangl (eds.). Transitions from education to work in Europe. The integration of youth into EU labour markets. Oxford University Press, Oxford, 23-62.

Neave, Guy (1980). The changing balance of power: Recent developments in provision for the 16-19 years age range in Europe. Comparative Education 16 (2), 93-105.

Nermo, Magnus (1996). Occupational sex segregation in Sweden, 1968-1991. Work and Occupations 23 (3), 319-332.

Odelholm, Hans (1998). UREG. Statistics Sweden document Dokureg.doc, dated 1998-91-09.

OECD (1998): Employment Outlook. Paris.

OECD (2001): Education at a glance. Paris.

Oppenheimer, Valerie Kincade (1994). Women's rising employment and the future of the family in industrial societies. Population and Development Review 20 (2), 293-342.

Rindfuss, Ronald R., and Larry L. Bumpass (1976). How old is too old? Age and the sociology of fertility. Family Planning Perspectives 8 (5), 226-230.

Rindfuss, Ronald R., Larry Bumpass, and Craig St. John (1980). Education and fertility: Implications for the roles women occupy. American Sociological Review 45, 431-447.

Rindfuss, Ronald R., S. Philip Morgan, and Karen Offutt (1996). Education and the changing age pattern of American fertility: 1963-1989. Demography 33 (3), 277-290. 
Rindfuss, Ronald R., Karen Benjamin Guzzo, and S. Philip Morgan (2003). The changing institutional context of low fertility. Population Research and Policy Review 22, 411-438.

Rønsen, Marit (2004). Fertility and family policy in Norway. A reflection on trends and possible connections. Demographic Research 10 (10). Available at http://www.demographic-research.org/

Rubery, Jill, Mark Smith, Colette Fagan and Damian Grimshaw (1998). Women and European Employment. Routledge, London.

Rusak, S.T. (1977). Sweden and Ontario under Palme and Davis: Educational Priorities. Comparative Education 13 (3), 199-221.

Salerno, Carlo (2002). Higher education in Sweden. CHEPS-higher education monitor, Country report. Center for Higher Education Policy Studies.

Shavit, Yossi and Hans-Peter Blossfeld (1996). Equalizing Educational Opportunity: Do Gender and Class Compete? In: Erikson, Robert and Jan O. Jonsson (eds.). Can Education Be Equalized? The Swedish Case in Comparative Perspective. Westview Press, Boulder, 233-253.

Shavit, Yossi and Walter Müller (2000). Vocational secondary education. Where diversion and where safety net? European Societies 2 (1), 29-50.

Smyth, Emer (2003): Gender Differentiation and Early Labour Market Integration across Europe. In: Kogan, Irene and Walter Müller (eds.). School-to-work Transitions in Europe: Analyses of the EU LFS 2000 Ad Hoc Module. Mannheimer Zentrum für Europäische Sozialforschung, Mannheim, 55-88.

Stanfors, Maria (2003): Education, labor force participation and changing fertility patterns. Lund Studies in Economic History 22. Almqvist \& Wiksell International, Stockholm.

Statistics Sweden (1996). Svensk utbildningsnomenklatur. Del 1; Systematisk version. Meddelanden i samordningsfrågor 1996:1.

Statistics Sweden (1997). Statistical Yearbook of Sweden 1997 (Statistiska Centralbyrån [1997]. Statistisk Årsbok '97). 
Surkyn, Johan and Ron Lesthaeghe (2004). Value Orientation and the Second Demographic Transition (SDT) in Northern, Western and Southern Europe: An Update. In: Andersson, Gunnar and Gerda Neyer (eds.): Contemporary research on European fertility: Perspectives and developments. Demographic Research, Special Collection 3, Article 3, 43-86: www.demographicresearch.org

The Swedish Institute (2004). Fact Sheets on Sweden. Higher education in Sweden. September 29, 2004: www.sweden.se

Tomasson, Richard F. (1965). From elitism to egalitarianism in Swedish education. Sociology of Education 38 (3), 203-223.

van de Kaa, Dirk J. (1987). Europe's second demographic transition. Population Bulletin 42, 1-57.

van de Kaa, Dirk J. (1996). Anchored narratives: The story and findings of half a century of research into the determinants of fertility. Population Studies 50, $389-432$.

Watkins, Susan Cotts (1995). Social networks and social science history. Social Science History 19 (3), 295-311,

West, Candace and Don H. Zimmerman (1987). Doing gender. Gender \& Society 1 (2), 125-151.

West, Candace and Sarah Fenstermaker (1995). Doing difference. Gender \& Society 9 (1), 8-37.

Wolbers, Maarten (2003). Job Mismatches and their Labour Market Effects among School Leavers in Europe. In: Kogan, Irene and Walter Müller (eds.). Schoolto-work Transitions in Europe: Analyses of the EU LFS 2000 Ad Hoc Module. Mannheimer Zentrum für Europäische Sozialforschung, Mannheim, 89-120. 
Figure 1. Per cent permanently childless, by educational group; Swedish women born in 1955-59

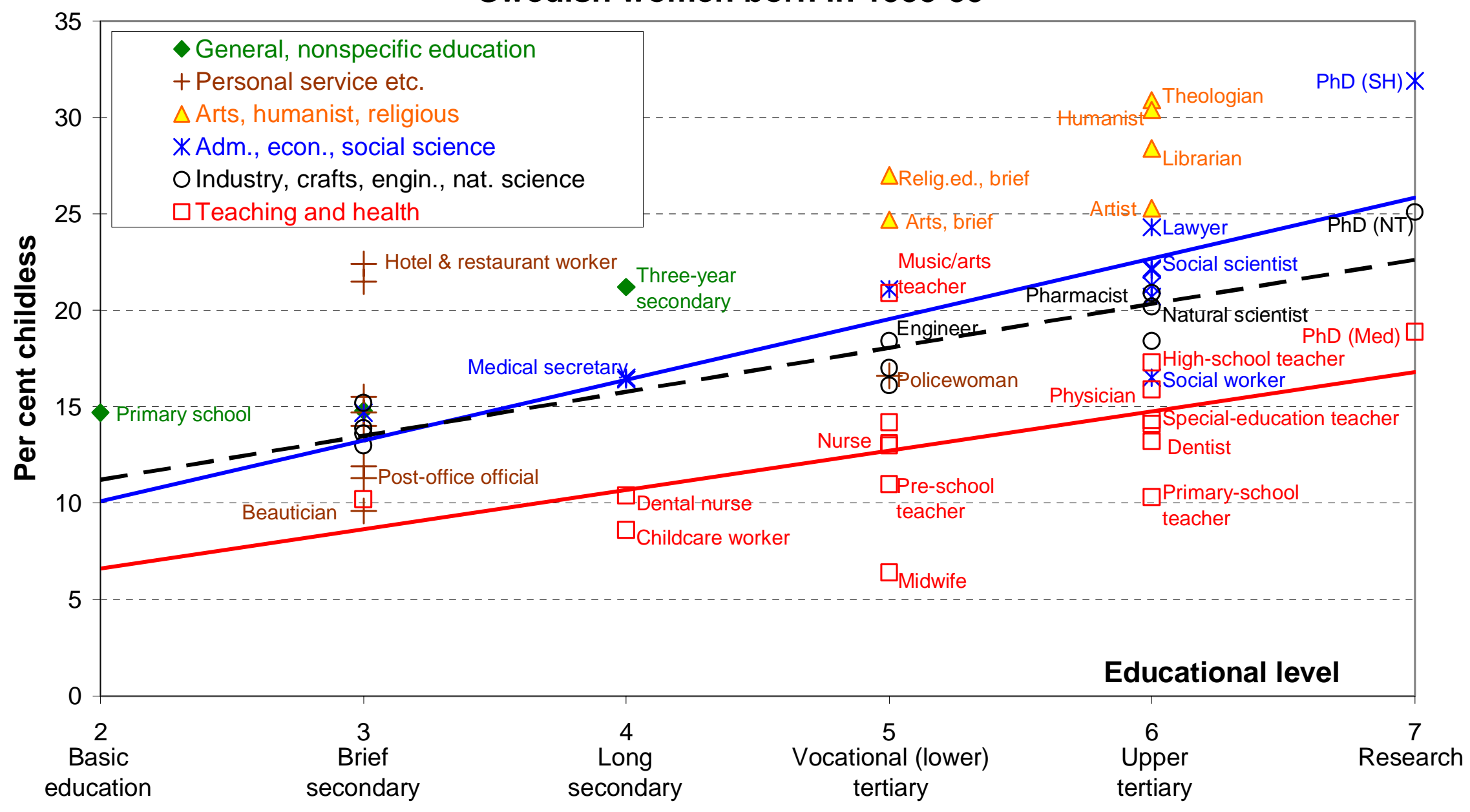


Figure 2. Per cent permanently childless, by mean age at completion of education; Swedish women born in 1955-59

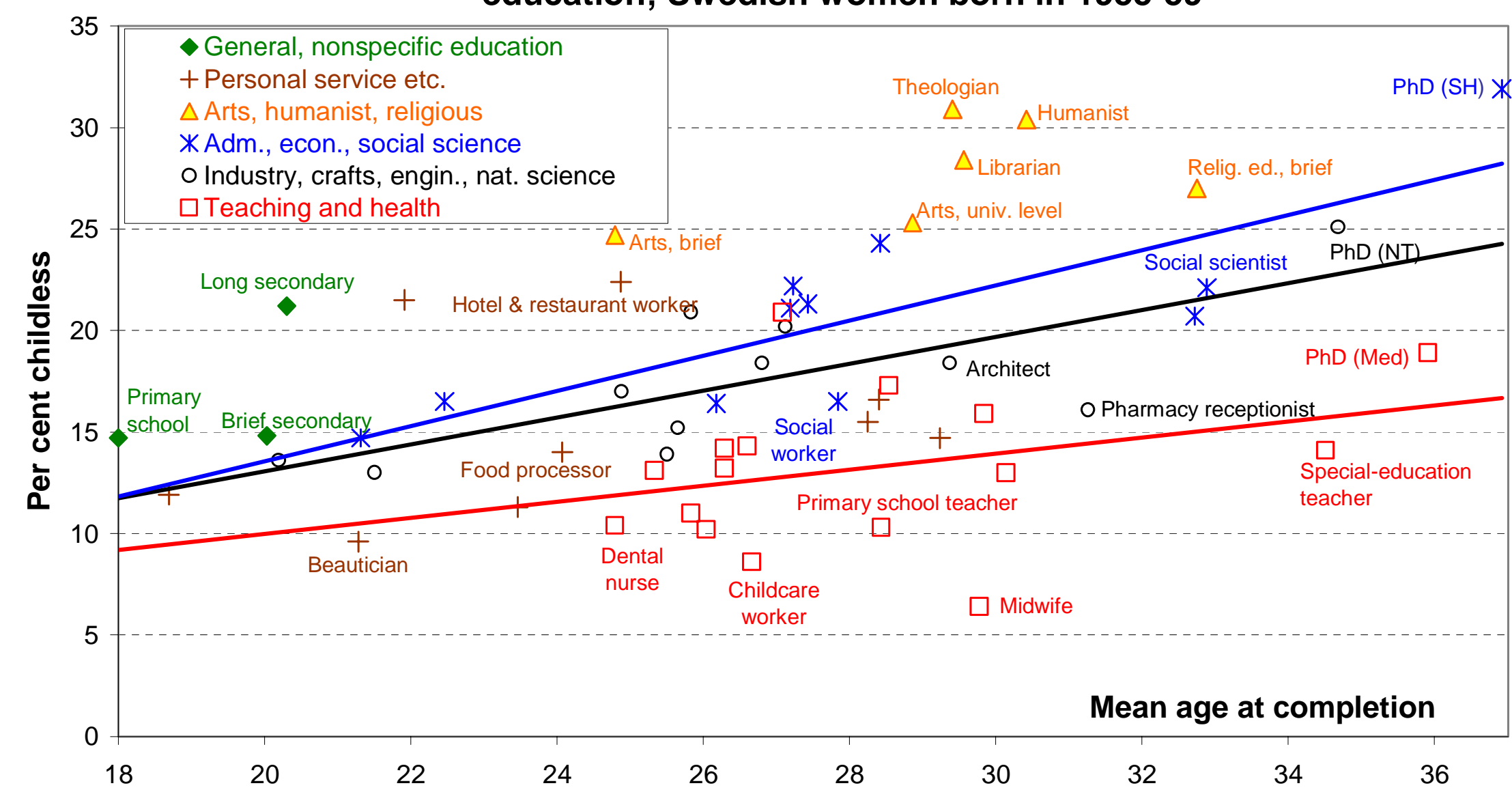


Figure 3. Per cent permanently childless vs. never married; Swedish women born in 1955-59

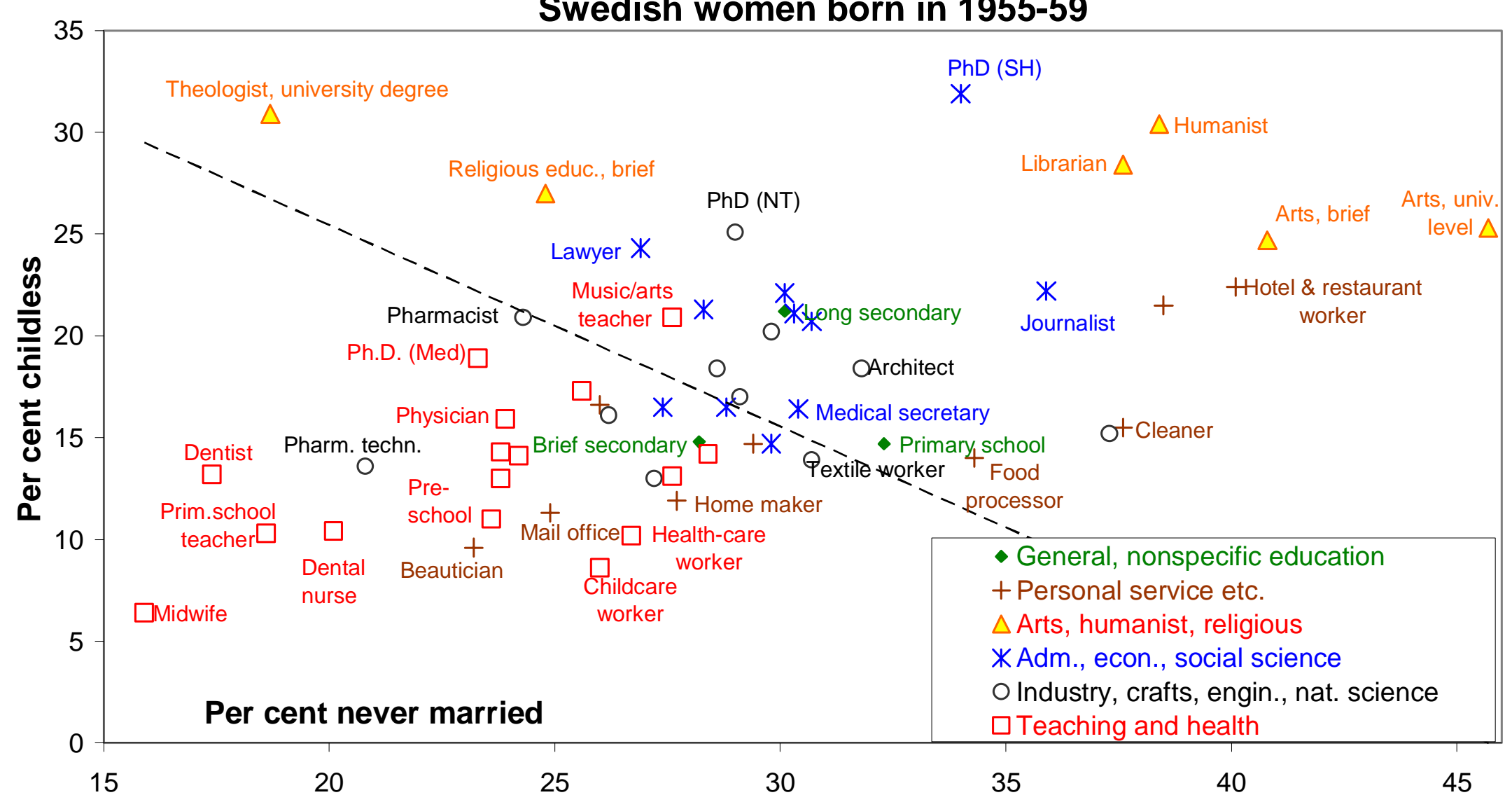




\section{Appendix 1: Data}

A1.1. The register data. We have access to individual-level data for all female members of the cohorts born since 1945 and domiciled in Sweden at any time since the census of 1960. Our data have been extracted from the Swedish educational register through the end of 1998 and combined with information for the same individuals from the (Swedish) central population register through $2002 .^{23}$

The central Swedish population register contains all demographic events recorded for the women we study, so long as the events occurred in Sweden. Births that occurred abroad are also recorded if the woman and her child(ren) subsequently entered Sweden. We know the women's own birthdates, all dates on which they have a recorded birth, marriage, divorce, or in- or out-migration across the country's borders, and any date of death. All dates are given to the accuracy of the day. For more details, see e.g. Section 2.1 in Hoem (1997).

In its current form, the educational register ${ }^{24}$ is based on information originating from the population censuses of 1985 and 1990, and from annual reports on course completion from the entire educational system in the country. For women who immigrated from abroad, Statistics Sweden has sought to fill lacunas through largescale mail inquiries, annually in recent years. In principle, the register should cover education completed in Sweden back through 1970 and beyond. For each individual, each entry contains a code for the education completed and it should also contain calendar year of completion. For the early years, the register covers mostly academic courses, but the ambition is to include all types of education. There has been great improvement in coverage and accuracy over the life of the register. Nevertheless, considerable problems remain with duplicate records and, particularly, with missing calendar years at attainment. Table A1 gives an overview of the quality of the records available for women born in Sweden in 1945 through 1964. By a process of elimina-

\footnotetext{
${ }^{23}$ We got an extension by four extra years from the population register as part of a standing data order that does not cover the educational register. We also have access to data (stemming from Swedish tax registers) on annual earnings and public transfers for our study objects during 1980-98. We have not really used the income data in the present study but hope to do so in a future continuation.

${ }^{24}$ For more information, see Odelholm (1998). Åke Nilsson (personal communication) has given us an update.
} 
tion based on the following considerations, we have decided to concentrate our current presentation on the cohort of women born in Sweden in 1955-59.

-- We are concerned with permanent childlessness in this paper, so we have wanted to study women most of whom have finished childbearing. This makes the youngest cohort in Table A1 somewhat less useful than the other cohorts.

-- The number of missing calendar years of educational attainment strikes us as a bit too high in the records of the cohort born in 1945-49. The cohort of 1950-54 may be a borderline case. Both cohorts, however, entered their education before the educational reform of 1962 and the reform of the higher education of 1977 . These reforms introduced the comprehensive school system and the main structure of tertiary education which are still in place in Sweden today. We have wanted a study whose results allow us to make some inferences about the current situation as well. Nevertheless, to test the validity of our results, we have handled both the cohort of 1950-54 and the cohort of 1960-64 in the same manner as that from 1955-59, and the results (not reported here) are largely the same as those that we do report.

-- We have not wanted to venture into the more problematic records for female immigrants in the register and have limited our study to women born in Sweden.

Table A1. Numbers of records and their completeness in the Swedish educational register as of the end of 1998 . Women born in Sweden

\begin{tabular}{|c|c|c|c|c|c|c|}
\hline $\begin{array}{c}\text { Year of } \\
\text { Birth }\end{array}$ & $\begin{array}{c}\text { Age at end } \\
\text { of } 1998^{\mathrm{a}}\end{array}$ & $\begin{array}{c}\text { Age at end } \\
\text { of } 2002^{b}\end{array}$ & $\begin{array}{c}\text { Total } \\
\text { persons }\end{array}$ & $\begin{array}{c}\text { Per cent } \\
\text { with complete } \\
\text { records }^{\mathrm{d}}\end{array}$ & $\begin{array}{c}\text { Per cent } \\
\text { with partially } \\
\text { complete records }\end{array}$ & $\begin{array}{c}\text { Per cent } \\
\text { with no ed years } \\
\text { recorded }^{\mathrm{f}}\end{array}$ \\
\hline $1945-49$ & 49-53 & 53-57 & 299,675 & 33 & 10 & 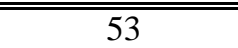 \\
\hline $1950-54$ & $44-48$ & $48-52$ & 256,287 & 45 & 12 & 42 \\
\hline $1955-59$ & $39-43$ & $43-47$ & 249,607 & 63 & 10 & 25 \\
\hline $1960-64$ & $34-38$ & $38-42$ & 258,657 & 71 & 10 & 18 \\
\hline & \multicolumn{6}{|l|}{ NOTES } \\
\hline & \multicolumn{6}{|c|}{${ }^{\mathrm{a}}$ Time of extraction of educational data } \\
\hline & \multicolumn{6}{|c|}{${ }^{b}$ Time of extraction of demographic data } \\
\hline & \multicolumn{6}{|c|}{${ }^{\mathrm{c}}$ Swedish-born women only } \\
\hline & \multicolumn{6}{|c|}{${ }^{\mathrm{d}}$ Per cent persons where all educational records show year of attainment } \\
\hline & \multicolumn{6}{|c|}{${ }^{\mathrm{e}}$ Per cent persons where some but not all educational records show year of attainment } \\
\hline
\end{tabular}


A1.2. Coding of educational attainment. In the Swedish statistical system, any recorded item of educational attainment is given a five-digit code (Statistics Sweden, 1996; with subsequent minor revisions). The first digit represents the general orientation of the education, largely as given in the legend to Figure 1. The second digit represents educational level, essentially as given on the $x$-axis of Figure 1 and as described further in connection with that diagram. The three final digits represent further sub-specification. For instance, the code 26731 is used for individuals educated in teaching (the digit 2) in a study-program that is supposed to take three years or longer and lead to a university-level degree (the digit 6) in the fields of mathematics (7), physics (3), and geography (1). In everyday terms 26731 indicates that this person has been educated as a high-school teacher in the mentioned subjects. The code 26732 is for corresponding teachers in mathematics, physics, and chemistry.

Potentially there are about 100,000 codes in this system. In practice, we have found about 2900 codes used for women born in Sweden. This is much too many categories for the kind of representation we use, so we have grouped them into some sixty meaningful types of education according to their characteristics. The resulting grouping is most easily evident in Table A2.

For our graphical representation, we have adapted the coding of the statistical system as follows.

-- The statistical system groups education for pharmaceutical work (pharmacy technicians, pharmacy receptionists, pharmacists, and laboratory assistants) under the health professions. We have reclassified them so they are together with women educated for the natural sciences because we feel that this better reflects the nature of their work and their workplace situation; women in pharmacy work are not concerned with clients as patients the way nurses and physicians are.

-- In Figure 1 we have used the same symbol to represent women educated for teaching and women educated for the health professions. We believe that their common orientation toward pupils and patients is more important than the fact that they come under different headings in the statistical system.

-- We have used one symbol to represent women educated for postal services (mail carriers, post-office employees) and for personal service (homemaking, cleaning, food processing, work in hotels and restaurants, beauticians, and so on). Women 
educated for police work have also been marked by the same symbol. This is just to simplify the diagram.

-- There are additional codes for education aimed at jobs in agriculture, and two of the categories (concerning women trained as farm workers) are listed in Table A2. Their childlessness fractions largely overlap with groups of women educated at similar levels for other kinds of non-caring and non-teaching jobs, ${ }^{25}$ and we have not included them in Figure 1 so as not to mess up the diagram needlessly with this small group.

-- With the combinations we have used, most of our educational groups have a reasonable size, but we have had to combine women with a doctorate in the humanities with women with a doctorate in the administrative and social sciences to get anything like a group that is big enough to avoid domination by random variation.

A1.3. Data cleaning. For our purposes, an ideal set of educational records for an individual would contain a sequence of accurate educational codes, each of which would be paired with a date of course completion that is accurate enough to (i) reflect real course completion and (ii) to avoid most ties, i.e., two or more codes with the same recorded times of completion for an individual. ${ }^{26}$ An accuracy of a calendar year is much too coarse for both of these purposes. Individuals can easily have two or more correct educational records in a single year, particularly since the Swedish educational register catches completions down to individual semester-length courses in many cases. Given the active dynamics of the Swedish educational system, an individual can also have a correct record of a lower-level education after a chronologically earlier correct record of a higher-level education. Such "disorder in the life-course" does not allow data-cleaning on the basis of a unidirectional and monotonic concept of the educational life-course.

Since the educational register has been built up successively over time, an additional complication arises when the register manager discovers that a younger and presumably more correct record disagrees with an older record, either in terms of edu-

\footnotetext{
${ }^{25}$ For instance, 20 per cent of female agronomists and veterinarians are childless in our cohort. This fraction is similar to that for other academics educated for jobs outside the teaching and health professions.

${ }^{26}$ Such a tie could actually be possible namely if, for example, someone studies at two lines and finishes them at the same time. Such coincidences are rare and we have disregarded them.
} 
cational code or recorded year of attainment. In the register, therefore, each record has an additional item, namely the year the item was recorded. This has been useful during our considerable cleaning of the educational data.

In our cleaning process, we have removed duplicate records and ties, for simplicity leaving at most one educational record per person per calendar year, covering the status at the end of the year. We have let a newer record supersede an earlier one with which it is inconsistent. And finally, where year of attainment was still missing, we have imputed one by inserting the cohort's average year of attainment for the given educational code, within constraints set by chronologically preceding and following records for the same individual. We computed this average empirically across individuals with the same educational code for which the year was recorded. Cleaning was made iteratively until convergence.

Note that this means that we have not inserted the year of attainment implied by a regular progress through the educational system, as defined normatively by official descriptions of educational lines, because the official description does not correspond even approximately to school realities. (Thus we have not imputed, say, the calendar year in which an individual attains age 19 for the completion of secondary school.) This is also evident from the column called "mean age at completion of education" in Table A2. Those mean ages are regularly much too high as compared to a normative description. Kravdal (2004) has shown that the assumption of a regular progress can be much inferior to empirical imputation.

If we accept the imputed missing years of completion, we can characterize each respondent's educational attainment for any year up through 1998 in our data. This feature has been useful for some experiments to be reported presently.

For the present paper, therefore, we have attempted to get as close as possible to each woman's highest educational attainment by the end of her educational career, and have used that attainment in our analyses, for instance in Figure 1 and Table A2.

In practice, we have settled for her educational attainment by the time of data extraction (viz., at the end of 1998). We have done so both for our main cohort (born in 1955-59 and thus aged 39-43 at that end-date) and in a supplementary analysis of the neighboring cohorts (aged 34-38 and 44-53, respectively, at the end-date). Note that the data for the two immediately older cohorts go to higher ages than the data for 
our youngest cohort. To make the cohorts more comparable, we have as an experiment also studied childlessness at the end of the reproductive period according to education completed by age 35 for each cohort. In the cohorts that we can follow to higher ages, there is considerable dynamics in recorded educational attainment after age 35. (See our companion paper for some such features; we do not otherwise report details of this nature.) Nevertheless, the results on permanent childlessness are only different in a minor way from what we record here, even when education is measured at age 35 . Such differences as we have found are easily attributable to random variation in the smallest of our educational groups. We get the same type of outcome when we study ultimate fertility in similar experiments made for our companion paper.

Women who have left or entered Sweden before the end of 1998, or for whom we have a death record before that date, represent a complication, which we have handled as follows. Those who left the country before the end of 1998 and for whom we have a subsequent return record, we have used educational status at the end of 1998, just as for the stationary population. For women who left Sweden before the end of 1998 and who did not return by that end-date, we have used their educational attainment at out-migration. For (the few) women who did not survive to the end of 1998, we have used educational attainment as recorded at death.

Out-migration and non-survival cause similar trivial problems for the definition of permanent childlessness. We have handled them as follows:

- For women who left the study population through death, we have used the childbearing records until death.

- For women who left the population by out-migration without returning before the end of the study period, we used the childbearing records until out-migration.

- For women who left the population by out-migration but then returned, the childbearing records were completed on subsequent in-migration, and we have used the complete childbearing records.

A1.4. Method of analysis. Our method of analysis is so straightforward that it does not really need any extensive description, but some comments may still be in order. We have concentrated on the final reproductive-lifetime outcome, and have computed the per cent permanently childless in each educational group, defined according to the highest level of education ultimately attained in our records. 
We would have liked to use event-history methods in our analysis as well, but with the current data set, we have not ventured down that road at the present stage. Despite all the strengths of the data from the educational register, there simply is too much uncertainty about the accuracy of the timing information in the educational histories of the cohorts that have completed their childbearing. ${ }^{27}$ Our current method has the merit of simplicity and the advantage that the procedure can be repeated for any country that has similar information on childbearing and educational attainment. We only get a pale reflection of the dynamics that constitute our main explanation of the patterns revealed. Nevertheless even this adds a new dimension to our understanding of the connection between education and childbearing.

In statistical terms, our procedure can be interpreted as follows: We are confronted with a two-dimensional outcome, with a childlessness indicator as one variable and final educational attainment (defined in terms of both level and field of education) as another. We study the structure of the distribution of the former variable, conditional on the outcome of the second. We trust that this structure gives us new insights into the underlying dynamics that we are really interested in.

To avoid the impression that we are making an error that we ourselves have often warned against, we want to underline that our procedure does not amount to anticipatory analysis (Kravdal 2004). We are conditioning on the final outcome of one process (educational attainment), but we do not study the timing of entry into motherhood in parts of the lifecycle before the time of that final educational outcome. Conditioning on the future of one dimension in a study of the dynamics of the other can produce well-known biases in findings about the latter, but we only study the final outcome of the childbearing process and not its dynamics, so those biases should not arise.

Our most important analytical tool at this stage of the present project is diagrams of the nature apparent in our figures. Our approach invites a case-by-case investigation of meaningful nominative educational groups. It mimics procedures often used in studies of occupation mortality, where a case-by-case discussion of the mortality in distinct nominative occupations is often used. We feel that we have gained much more insight from this practice than by only using a woman's educational level,

\footnotetext{
${ }^{27}$ A study by Lappegård and Rønsen (2005) suggests that our Norwegian colleagues have more adequate data at their disposal, or else they are more courageous than us.
} 
let alone by representing that level by the number of years of education she is supposed to use to reach that level, as is often done. The nominative groups much more easily inspire substantive explanation and theory formation, reveal open questions, and easily provide counter-examples for theory elements that do not stand up to closer scrutiny. 


\section{Appendix 2}

Table A2. Basic childbearing statistics for Swedish women born in 1955-59 (page 1)

\begin{tabular}{|c|c|c|c|c|c|c|c|c|c|c|c|}
\hline & $\begin{array}{l}\text { Edu } \\
\text { level }\end{array}$ & All & $\begin{array}{l}\text { Per } \\
\text { cent } \\
\text { child- } \\
\text { less }\end{array}$ & $\begin{array}{l}\text { Per cent } \\
\text { with } 2 \\
\text { or more } \\
\text { children }\end{array}$ & $\begin{array}{c}\text { Mean } \\
\text { number } \\
\text { of } \\
\text { children }\end{array}$ & $\begin{array}{c}\text { Per } \\
\text { cent } \\
\text { never } \\
\text { married }\end{array}$ & $\begin{array}{c}\text { Mean } \\
\text { number } \\
\text { children } \\
\text { (never } \\
\text { married) }\end{array}$ & $\begin{array}{c}\text { Mean } \\
\text { number } \\
\text { children } \\
\text { (ever } \\
\text { married) }\end{array}$ & $\begin{array}{c}\text { Mean } \\
\text { number } \\
\text { of } \\
\text { children } \\
\text { (mothers) }\end{array}$ & $\begin{array}{l}\text { Mean } \\
\text { age } \\
\text { at first } \\
\text { birth }\end{array}$ & $\begin{array}{c}\text { Mean age at } \\
\text { completion } \\
\text { of } \\
\text { education }\end{array}$ \\
\hline Unknown & & 4361 & 79.1 & 10.6 & 0.37 & 74.0 & 0.20 & 0.86 & 1.78 & 23.36 & \\
\hline \multicolumn{12}{|l|}{ General education, non specific } \\
\hline Primary school & 2 & 39102 & 14.7 & 71.0 & 2.12 & 32.3 & 1.43 & 2.46 & 2.49 & 23.14 & 17.99 \\
\hline Brief secondary school, general & 3 & 10416 & 14.8 & 70.8 & 1.94 & 28.2 & 1.23 & 2.22 & 2.28 & 25.86 & 20.02 \\
\hline Long secondary school, general & 4 & 8195 & 21.2 & 65.0 & 1.78 & 30.1 & 0.96 & 2.13 & 2.26 & 27.68 & 20.29 \\
\hline \multicolumn{12}{|l|}{ Arts, humanist, religious } \\
\hline Religious education, brief & 5 & 326 & 27.0 & 61.3 & 1.92 & 24.8 & 0.49 & 2.39 & 2.63 & 27.16 & 32.74 \\
\hline Theology, university degree & 6 & 246 & 30.9 & 56.9 & 1.69 & 18.7 & 0.04 & 2.07 & 2.45 & 29.62 & 29.40 \\
\hline Arts, brief & 5 & 1061 & 24.7 & 59.2 & 1.65 & 40.8 & 1.08 & 2.04 & 2.19 & 28.27 & 24.78 \\
\hline Arts, university-level degree & 6 & 838 & 25.3 & 53.9 & 1.52 & 45.7 & 1.08 & 1.89 & 2.04 & 30.90 & 28.85 \\
\hline $\begin{array}{l}\text { Humanities, university degree (not } \\
\text { teacher) }\end{array}$ & 6 & 908 & 30.4 & 54.0 & 1.47 & 38.4 & 0.76 & 1.91 & 2.11 & 30.17 & 30.41 \\
\hline Librarian & 6 & 577 & 28.4 & 58.2 & 1.56 & 37.6 & 0.79 & 2.03 & 2.18 & 30.46 & 29.55 \\
\hline
\end{tabular}


Table A2. Basic childbearing statistics for Swedish women born in 1955-59 (page 2)

\begin{tabular}{|c|c|c|c|c|c|c|c|c|c|c|c|}
\hline & $\begin{array}{l}\text { Edu } \\
\text { level }\end{array}$ & All & $\begin{array}{c}\text { Per } \\
\text { cent } \\
\text { child- } \\
\text { less }\end{array}$ & $\begin{array}{l}\text { Per cent } \\
\text { with } 2 \\
\text { or more } \\
\text { children }\end{array}$ & $\begin{array}{c}\text { Mean } \\
\text { number } \\
\text { of } \\
\text { children }\end{array}$ & $\begin{array}{c}\text { Per } \\
\text { cent } \\
\text { never } \\
\text { married } \\
\end{array}$ & $\begin{array}{c}\text { Mean } \\
\text { number } \\
\text { children } \\
\text { (never } \\
\text { married) }\end{array}$ & $\begin{array}{c}\text { Mean } \\
\text { number } \\
\text { children } \\
\text { (ever } \\
\text { married) }\end{array}$ & $\begin{array}{c}\text { Mean } \\
\text { number } \\
\text { of } \\
\text { children } \\
\text { (mothers) }\end{array}$ & $\begin{array}{l}\text { Mean } \\
\text { age } \\
\text { at first } \\
\text { birth }\end{array}$ & $\begin{array}{c}\text { Mean age at } \\
\text { completion } \\
\text { of } \\
\text { education }\end{array}$ \\
\hline \multicolumn{12}{|l|}{ Personal service etc. } \\
\hline Home maker & 3 & 6897 & 11.9 & 76.0 & 2.14 & 27.7 & 1.45 & 2.40 & 2.43 & 24.59 & 18.68 \\
\hline Cleaner & 3 & 524 & 15.5 & 65.3 & 1.95 & 37.6 & 1.37 & 2.30 & 2.31 & 22.63 & 28.24 \\
\hline Food processing & 3 & 3098 & 14.0 & 70.1 & 2.07 & 34.3 & 1.45 & 2.40 & 2.41 & 24.16 & 24.06 \\
\hline Hotel \& restaurant worker & 3 & 411 & 22.4 & 61.6 & 1.71 & 40.1 & 1.25 & 2.02 & 2.21 & 26.79 & 24.86 \\
\hline Service worker, unspecified & 3 & 130 & 21.5 & 68.5 & 1.96 & 38.5 & 1.36 & 2.34 & 2.50 & 23.96 & 21.90 \\
\hline Beautician, hairdresser & 3 & 1580 & 9.6 & 75.9 & 2.02 & 23.2 & 1.42 & 2.20 & 2.23 & 25.40 & 21.27 \\
\hline Grand-household administrator & 5 & 444 & 21.6 & 66.2 & 1.75 & 26.4 & 0.84 & 2.08 & 2.24 & 28.89 & 26.87 \\
\hline Policewoman & 5 & 716 & 16.6 & 69.3 & 1.83 & 26.0 & 1.04 & 2.11 & 2.20 & 28.33 & 28.39 \\
\hline Mail carrier & 3 & 688 & 14.7 & 73.8 & 2.09 & 29.4 & 1.41 & 2.37 & 2.44 & 23.52 & 29.23 \\
\hline Mail office worker & 3 & 1020 & 11.3 & 76.0 & 2.04 & 24.9 & 1.45 & 2.23 & 2.30 & 24.57 & 23.45 \\
\hline \multicolumn{12}{|l|}{ Admin., econom., social science } \\
\hline Administration, brief secondary & 3 & 25065 & 14.7 & 69.5 & 1.89 & 29.8 & 1.24 & 2.17 & 2.22 & 25.26 & 21.30 \\
\hline Business administration, brief secondary & 4 & 8257 & 16.5 & 69.5 & 1.83 & 27.4 & 1.12 & 2.10 & 2.19 & 26.65 & 22.45 \\
\hline Business administration, long secondary & 5 & 5191 & 21.1 & 62.1 & 1.65 & 30.3 & 0.95 & 1.95 & 2.09 & 28.62 & 27.18 \\
\hline $\begin{array}{l}\text { Business administration, university } \\
\text { degree }\end{array}$ & 6 & 4570 & 21.3 & 63.8 & 1.68 & 28.3 & 0.89 & 1.99 & 2.13 & 30.36 & 27.42 \\
\hline Medical secretary & 4 & 2099 & 16.4 & 69.4 & 1.86 & 30.4 & 1.12 & 2.18 & 2.23 & 25.85 & 26.17 \\
\hline Journalist & 6 & 465 & 22.2 & 62.2 & 1.66 & 35.9 & 1.05 & 2.00 & 2.13 & 30.11 & 27.22 \\
\hline Social worker & 6 & 3282 & 16.5 & 68.4 & 1.88 & 28.8 & 2.16 & 2.16 & 2.25 & 28.45 & 27.83 \\
\hline Psychologist & 6 & 579 & 20.7 & 61.3 & 1.72 & 30.7 & 2.10 & 2.10 & 2.17 & 29.34 & 32.71 \\
\hline Lawyer & 6 & 1255 & 24.3 & 61.8 & 1.64 & 26.9 & 0.75 & 1.97 & 2.16 & 30.92 & 28.41 \\
\hline Social science, university degree & 6 & 1401 & 22.1 & 61.9 & 1.66 & 30.1 & 0.83 & 2.01 & 2.13 & 28.78 & 32.88 \\
\hline
\end{tabular}


Table A2. Basic childbearing statistics for Swedish women born in 1955-59 (page 3)

\begin{tabular}{|c|c|c|c|c|c|c|c|c|c|c|c|}
\hline & $\begin{array}{l}\text { Edu } \\
\text { level }\end{array}$ & All & $\begin{array}{c}\text { Per } \\
\text { cent } \\
\text { child- } \\
\text { less }\end{array}$ & $\begin{array}{l}\text { Per cent } \\
\text { with } 2 \\
\text { or more } \\
\text { children }\end{array}$ & $\begin{array}{c}\text { Mean } \\
\text { number } \\
\text { of } \\
\text { children }\end{array}$ & $\begin{array}{c}\text { Per } \\
\text { cent } \\
\text { never } \\
\text { married }\end{array}$ & $\begin{array}{c}\text { Mean } \\
\text { number } \\
\text { children } \\
\text { (never } \\
\text { married) }\end{array}$ & $\begin{array}{c}\text { Mean } \\
\text { number } \\
\text { children } \\
\text { (ever } \\
\text { married) }\end{array}$ & $\begin{array}{c}\text { Mean } \\
\text { number } \\
\text { of } \\
\text { children } \\
\text { (mothers) }\end{array}$ & $\begin{array}{l}\text { Mean } \\
\text { age } \\
\text { at first } \\
\text { birth }\end{array}$ & $\begin{array}{c}\text { Mean age at } \\
\text { completion } \\
\text { of } \\
\text { education }\end{array}$ \\
\hline \multicolumn{12}{|l|}{$\begin{array}{l}\text { Industry, crafts, engineering, natural } \\
\text { science }\end{array}$} \\
\hline Mechanic etc., brief secondary & 3 & 3574 & 15.2 & 66.7 & 2.03 & 37.0 & 1.44 & 2.39 & 2.40 & 23.90 & 25.64 \\
\hline Textile worker & 3 & 2309 & 13.9 & 71.6 & 2.06 & 31.0 & 1.32 & 2.39 & 2.39 & 25.44 & 25.49 \\
\hline Mapmaker & 3 & 471 & 13.0 & 71.8 & 1.94 & 27.0 & 1.30 & 2.19 & 2.23 & 26.40 & 21.49 \\
\hline Engineer, advanced vocational training & 5 & 1421 & 18.4 & 65.9 & 1.76 & 29.0 & 1.03 & 2.06 & 2.16 & 27.79 & 26.79 \\
\hline $\begin{array}{l}\text { Natural sci.\&engineering, university } \\
\text { degree }\end{array}$ & 6 & 2057 & 20.2 & 68.7 & 1.79 & 30.0 & 0.99 & 2.14 & 2.25 & 30.60 & 27.10 \\
\hline Architect & 6 & 321 & 18.4 & 69.2 & 1.83 & 31.8 & 1.17 & 2.13 & 2.24 & 30.58 & 29.36 \\
\hline Pharmacy technician & 3 & 279 & 13.6 & 76.0 & 1.95 & 20.8 & 1.19 & 2.15 & 2.26 & 26.21 & 20.18 \\
\hline Pharmacy receptionist & 5 & 504 & 16.1 & 73.2 & 1.84 & 26.2 & 0.94 & 2.16 & 2.19 & 28.05 & 31.25 \\
\hline Pharmacist & 6 & 177 & 20.9 & 69.5 & 1.75 & 24.3 & 0.93 & 2.01 & 2.21 & 30.69 & 25.82 \\
\hline Laboratory assistant & 5 & 2026 & 17.0 & 72.0 & 1.88 & 29.1 & 1.10 & 2.21 & 2.27 & 28.27 & 24.87 \\
\hline \multicolumn{12}{|l|}{ Agriculture } \\
\hline Farm worker, brief secondary & 3 & 1786 & 15.5 & 72.1 & 2.11 & 35.0 & 1.36 & 2.51 & 2.49 & 26.97 & 24.19 \\
\hline Agronomist, veterinarian & 6 & 501 & 22.0 & 67.1 & 1.86 & 38.9 & 1.10 & 2.35 & 2.38 & 31.45 & 28.78 \\
\hline
\end{tabular}


Table A2. Basic childbearing statistics for Swedish women born in 1955-59 (page 4)

\begin{tabular}{|c|c|c|c|c|c|c|c|c|c|c|c|}
\hline & $\begin{array}{c}\text { Edu } \\
\text { level }\end{array}$ & All & $\begin{array}{l}\text { Per } \\
\text { cent } \\
\text { child- } \\
\text { less }\end{array}$ & $\begin{array}{c}\text { Per cent } \\
\text { with } 2 \\
\text { or more } \\
\text { children }\end{array}$ & $\begin{array}{c}\text { Mean } \\
\text { number } \\
\text { of } \\
\text { children }\end{array}$ & $\begin{array}{c}\text { Per } \\
\text { cent } \\
\text { never } \\
\text { married }\end{array}$ & $\begin{array}{l}\text { Mean } \\
\text { number } \\
\text { children } \\
\text { (never } \\
\text { married) }\end{array}$ & $\begin{array}{c}\text { Mean } \\
\text { number } \\
\text { children } \\
\text { (ever } \\
\text { married) }\end{array}$ & $\begin{array}{c}\text { Mean } \\
\text { number } \\
\text { of } \\
\text { children } \\
\text { (mothers) }\end{array}$ & $\begin{array}{l}\text { Mean } \\
\text { age } \\
\text { at first } \\
\text { birth }\end{array}$ & $\begin{array}{c}\text { Mean age at } \\
\text { completion } \\
\text { of } \\
\text { education }\end{array}$ \\
\hline \multicolumn{12}{|l|}{ Health professions } \\
\hline Health-care worker & 3 & 26456 & 10.2 & 77.4 & 2.19 & 26.7 & 1.55 & 2.42 & 2.44 & 24.12 & 26.03 \\
\hline Child-care worker & 4 & 12673 & 8.6 & 80.2 & 2.26 & 26.0 & 1.63 & 2.49 & 2.48 & 24.19 & 26.65 \\
\hline Nurse & 5 & 17539 & 13.0 & 75.3 & 2.06 & 23.8 & 1.20 & 2.33 & 2.37 & 27.34 & 30.13 \\
\hline Midwife & 5 & 529 & 6.4 & 85.8 & 2.39 & 15.9 & 1.45 & 2.57 & 2.56 & 27.44 & 29.76 \\
\hline Physician & 6 & 1488 & 15.9 & 73.1 & 2.02 & 23.9 & 1.07 & 2.32 & 2.40 & 30.22 & 29.83 \\
\hline Ph.D. (Med) & 7 & 296 & 18.9 & 65.5 & 1.77 & 23.3 & 1.03 & 1.99 & 2.18 & 30.74 & 35.90 \\
\hline Dental nurse etc. & 4 & 3372 & 10.4 & 76.2 & 1.98 & 20.1 & 1.34 & 2.14 & 2.21 & 26.74 & 24.78 \\
\hline Dentist & 6 & 824 & 13.2 & 76.8 & 2.02 & 17.4 & 1.04 & 2.23 & 2.33 & 30.43 & 26.28 \\
\hline \multicolumn{12}{|l|}{ Teaching } \\
\hline Pre-school teacher & 5 & 13188 & 11.0 & 78.7 & 2.10 & 23.6 & 1.36 & 2.33 & 2.36 & 27.02 & 25.82 \\
\hline Youth worker & 5 & 4007 & 14.2 & 73.8 & 2.00 & 28.4 & 1.23 & 2.31 & 2.34 & 27.43 & 26.28 \\
\hline Physical education, teacher & 5 & 467 & 13.1 & 76.4 & 2.02 & 27.6 & 1.33 & 2.28 & 2.32 & 29.84 & 25.32 \\
\hline Primary-school teacher & 6 & 4038 & 10.3 & 80.2 & 2.19 & 18.6 & 1.33 & 2.39 & 2.44 & 27.64 & 28.42 \\
\hline Music or arts teacher & 5 & 1062 & 20.9 & 67.1 & 1.86 & 27.6 & 0.95 & 2.20 & 2.35 & 29.45 & 27.07 \\
\hline Home-economics teacher & 6 & 1039 & 14.3 & 75.1 & 2.06 & 23.8 & 1.20 & 2.32 & 2.40 & 28.95 & 26.59 \\
\hline Teacher of children with special needs & 6 & 823 & 14.1 & 73.1 & 1.94 & 24.2 & 1.17 & 2.18 & 2.25 & 28.27 & 34.50 \\
\hline High-school teacher & 6 & 2118 & 17.3 & 70.9 & 1.94 & 25.6 & 1.07 & 2.24 & 2.34 & 29.75 & 28.53 \\
\hline
\end{tabular}


Table A2. Basic childbearing statistics for Swedish women born in 1955-59 (page 5)

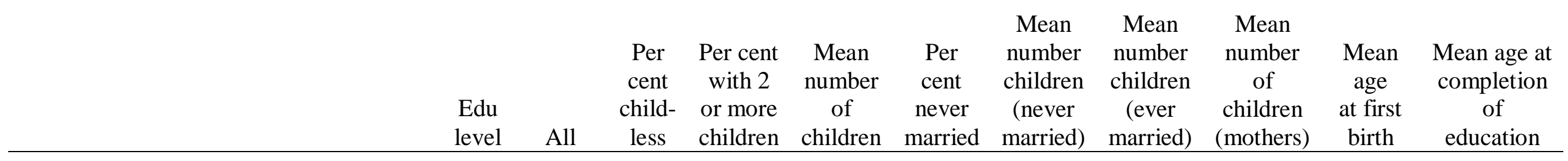

Nonmedical research

\begin{tabular}{lrrrrrrrrrrr}
\hline Ph.D. (Social Science or Humanities) & 7 & 191 & 31.9 & 47.6 & 1.37 & 34.0 & 0.65 & 1.75 & 2.02 & 30.31 & 36.91 \\
Ph.D. (Natural or Techn. Science) & 7 & 442 & 25.1 & 62.7 & 1.66 & 29.0 & 0.76 & 2.03 & 2.22 & 31.25 & 34.67 \\
& & & & & & & & & \\
& & 2294 & 20.7 & 63.9 & 1.84 & 36.7 & 1.15 & 2.23 & 2.31 & 25.88 & 25.51 \\
Known but unspecified education & & 249607 & 15.7 & 70.8 & 1.97 & 29.3 & 1.23 & 2.28 & 2.34 & 25.84 & 24.34
\end{tabular}

(including 3949 women in small odd groups) 